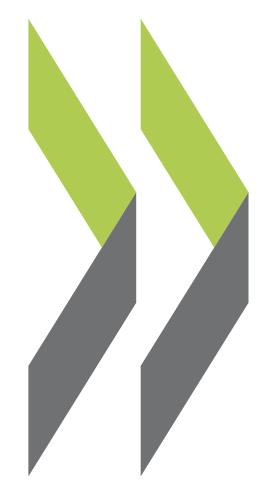

OECD Economics Department Working Papers No. 1293

\title{
Growing together: Towards a more inclusive Ireland
}

\section{David Haugh,}

Yosuke Jin,

\section{Alberto González Pandiella}




\section{Unclassified}

ECO/WKP(2016)17

Organisation de Coopération et de Développement Économiques

Organisation for Economic Co-operation and Development

13-Apr-2016

ECONOMICS DEPARTMENT

English - Or. English

GROWING TOGETHER: TOWARDS A MORE INCLUSIVE IRELAND

ECONOMIC DEPARTMENT WORKING PAPERS No. 1293

By David Haugh, Yosuke Jin, Patrick Lenain and Alberto Gonzalez Pandiella

OECD Working Papers should not be reported as representing the official views of the OECD or of its member countries. The opinions expressed and arguments employed are those of the author $(s)$.

Authorised for publication by Robert Ford, Deputy Director, Country Studies Branch, Economics Department.

All Economics Department Working Papers are available at www.oecd.org/eco/workingpapers

JT03393994

Complete document available on OLIS in its original format

This document and any map included herein are without prejudice to the status of or sovereignty over any territory, to the delimitation of international frontiers and boundaries and to the name of any territory, city or area. 
OECD Working Papers should not be reported as representing the official views of the OECD or of its member countries. The opinions expressed and arguments employed are those of the author(s).

Working Papers describe preliminary results or research in progress by the author(s) and are published to stimulate discussion on a broad range of issues on which the OECD works.

Comments on Working Papers are welcomed, and may be sent to the Economics Department, OECD, 2 rue André-Pascal, 75775 Paris Cedex 16, France, or by e-mail to eco.contact@oecd.org.

All Economics Department Working Papers are available at www.oecd.org/eco/workingpapers.

This document and any map included herein are without prejudice to the status of or sovereignty over any territory, to the delimitation of international frontiers and boundaries and to the name of any territory, city or area.

The statistical data for Israel are supplied by and under the responsibility of the relevant Israeli authorities. The use of such data by the OECD is without prejudice to the status of the Golan Heights, East Jerusalem and Israeli settlements in the West Bank under the terms of international law.

\section{(C) OECD (2016)}

You can copy, download or print OECD content for your own use, and you can include excerpts from OECD publications, databases and multimedia products in your own documents, presentations, blogs, websites and teaching materials, provided that suitable acknowledgment of OECD as source and copyright owner is given. All requests for commercial use and translation rights should be submitted to rights@oecd.org 


\section{ABSTRACT/RÉSUMÉ Growing together: Towards a more inclusive Ireland}

The Irish economy is growing strongly, but there is a risk many households will be left behind despite robust growth. High joblessness especially among the low-educated and skill-biased wage differentials have induced high market income inequality, among the highest in the OECD. Ireland's comprehensive welfare system provides a broad range of social benefits, which keeps jobless households out of poverty, but this reduces the financial incentives to work, especially for families with children. Structural unemployment is also explained by the lack of skills required to find employment in the Irish labour market, where the presence of multinational enterprises increases the reward for high skills and the penalty for poor skills. With the unemployed pool lacking the right skills and financial incentives, employers tend to resort to foreign workers, a practice facilitated by the well-functioning migration system. Getting more people into work is important to share the benefits of the recovery as widely as possible. This requires building up work capacity, especially by improving jobseekers' training, and ensuring welfare recipients honour their Job Path commitments in return. More needs to be done to increase incentive to work by reducing welfare and low-income traps. This should be done by shifting the tax burden from labour to indirect taxes in a progressive way that does not harm the lowest income groups.

Classification JEL : E2, E24, J01, J08, J6

Keywords: labour market reform, turnover, skills, productivity, innovations, entrepreneurship

(www.oecd.org/eco/surveys/economic-survey-ireland.htm).

****************************** $*$ *

\section{Grandir ensemble: Vers une Irlande plus inclusive}

La croissance de l'économie irlandaise est forte, mais il y a un risque que nombreux ménages restent à l'écart de cette croissance robuste. Le chômage élevé, surtout parmi les personnes peu instruites, et les différences de salaires basées sur les compétences, ont induit une forte inégalité des revenus avant impôts et transferts, , qui se situe parmi les plus élevées de l'OCDE. Le système de protection sociale élargi de l'Irlande offre une vaste gamme de prestations sociales, qui évite la pauvreté pour les ménages sans emploi , mais qui réduit les incitations financières au travail, en particulier pour les familles avec enfants. Le chômage structurel est également expliqué par le manque de compétences nécessaires pour trouver un emploi sur le marché du travail irlandais, où les entreprises multinationales recherchent des compétences élevées, ce qui pénalise qui n'ont pas les qualifications requises. Etant donné que les demandeurs d'emploi irlandais n'ont souvent pas les compétences requises et font face à peu d'incitations financières, les employeurs ont tendance à recourir à des travailleurs étrangers, une pratique facilitée par le système dímmigration qui fonctionne bien. Faciliter le retour à l'emploi est important pour parvenir à un partage partager des fruits de la reprise aussi large que possible. Cela nécessite d'améliorer le socle des compétences, et notamment la formation des demandeurs d'emploi, et d'assurer que les bénéficiaires de prestations sociales respectent leurs engagements en termes de retour à l'emploi. Plus doit être fait pour accroître les incitations au travail et pour réduire les trappes dans les bas revenus et les prestations sociales, . Cela devrait être fait en transférant la pression fiscale pesant sur le travail vers les impôts indirects, d'une manière progressive afin de ne pas nuire pas aux groupes à faible revenu.

Classification JEL: E2, E24, J01, J08, J6

Keywords: réforme du marché du travail, turnover, compétence, productivité, entrepreneuriat

(www.oecd.org/fr/eco/etudes/etude-economique-irlande.htm). 


\section{TABLE OF CONTENTS}

GROWING TOGETHER: TOWARDS A MORE INCLUSIVE IRELAND ............................................6

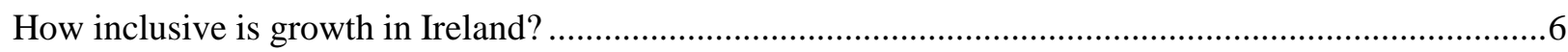

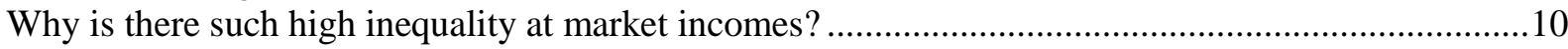

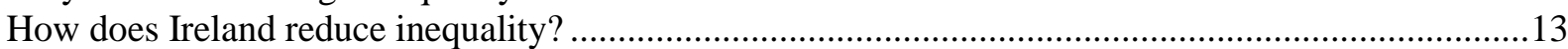

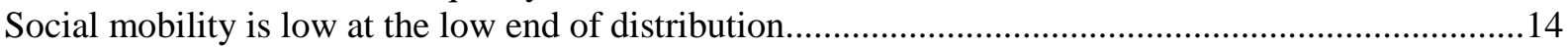

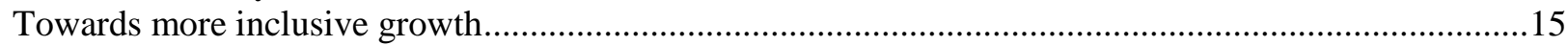

Building skills and getting more people back into work ...................................................................15

Using active labour market policies to boost employment ................................................................18

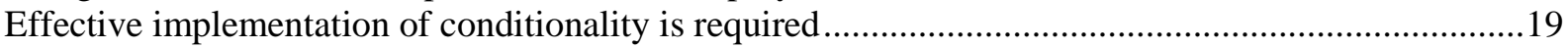

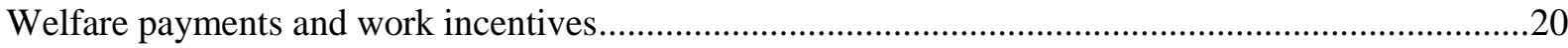

Fostering inclusive growth through fairer and more efficient welfare and taxation ................................20

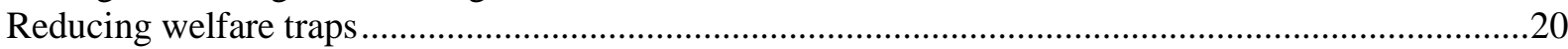

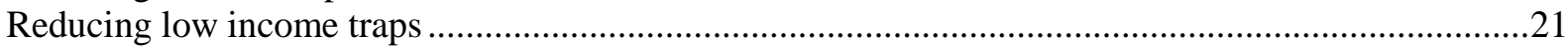

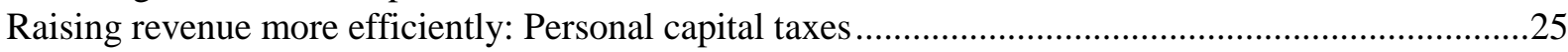

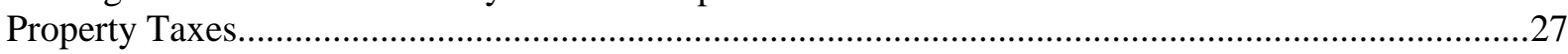

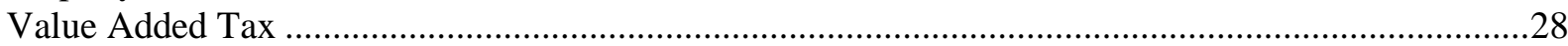

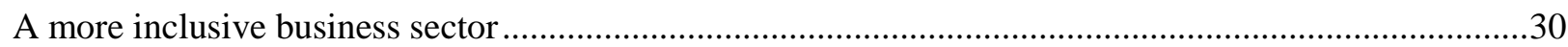

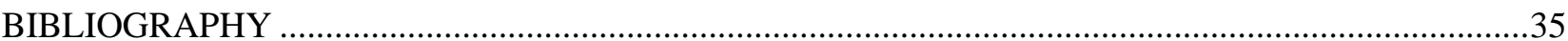

\section{Tables}

1. High shares of labour earnings are concentrated at the top and bottom of the scale ........................10

2. The low-educated are more likely to be jobless than the OECD average.......................................13

3. Assets are distributed unevenly across income and socio-economic groups...................................15

4. Tax Rates and Bands: Actual and Alternative Scenarios...............................................................2.

5. The marginal effective tax rate for the low paid can be reduced by changing in-work benefits ........25

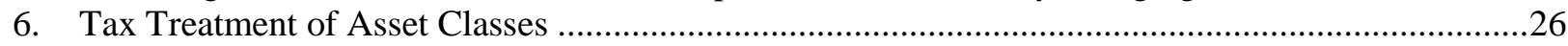

\section{Figures}

1. Ireland's market income GINI is the highest in the OECD ..........................................................

2. Ireland's disposable income GINI is below the OECD average....................................................

3. The increase in market income inequality in Ireland was largely driven by employment effects ........8

4. Internationally income is becoming more concentrated at the top .................................................

5. Share of the Bottom 20\% Households in Market Income is low in Ireland .......................................

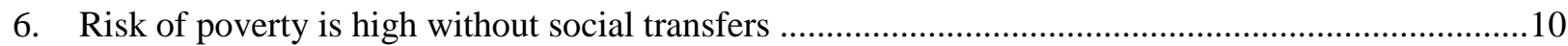

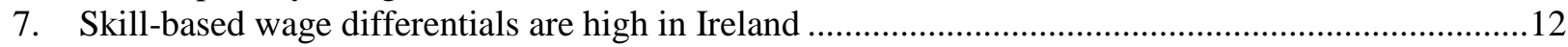




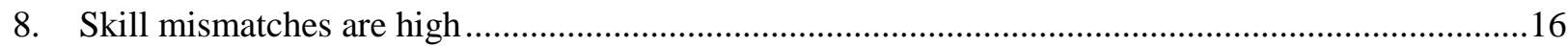

9. A low proportion of population have high skills ........................................................................17

10. Average Tax Wedge is low for the low paid and close to the OECD average for the higher paid.22

11. Some undesirable jumps in the marginal effective tax rate are built into the current system .........23

12. Lower income households with children face additional disincentives to work .............................24

13. Taxes on Property are low by international standards .............................................................2

14. The standard VAT rate is high but the revenue base is narrow ..................................................29

\section{Boxes}

Box 1. Corporate Investment in Human Capital .32

Recommendations for increasing the inclusiveness of growth ..............................................................33 


\section{GROWING TOGETHER: TOWARDS A MORE INCLUSIVE IRELAND}

\section{David Haugh, Yosuke Jin, Patrick Lenain and Alberto Gonzalez Pandiella ${ }^{l}$}

Ireland faces the challenge of having a high share of its population being unemployed or inactive, and thus receiving no labour earnings. High joblessness especially among the low-educated and large skillbiased wage differentials have induced high market income inequality. These features were already visible before the crisis, suggesting that the problem is largely structural. Although Ireland's welfare system provides a range of social transfers to reduce disposable income inequality and combat poverty, staying out of work for long periods of time undermines the well-being of families, with pervasive effects across generations. Getting more people back into work will therefore be key. To increase inclusion, while minimising distortions to growth, Ireland needs to:

- Facilitate the return to work of the unemployed by helping build-up work capacity, notably the acquisition of adequate skills, while making welfare conditional on beneficiaries honouring their Job-Path commitments;

- Improve the incentives to work by reducing welfare and income traps;

- Raising revenue more efficiently and equitably by continuing to shift the taxation burden away from labour taxes towards indirect taxes in a progressive way that does not harm the lowest income groups.

\section{How inclusive is growth in Ireland?}

Ireland's high structural unemployment and low labour-market participation results in large groups of households being left without labour income and relying almost exclusively on social transfers to make ends meet.

\footnotetext{
${ }^{1}$ The authors would like to thank Patrick Lenain, Bob Ford, Brendan O'Connor and David Hegarty for helpful comments on this paper, Damien Azzopardi, Penelope Silice and Elika Athari for statistical research assistance and Brigitte Beyeler for administrative support. This paper is also as a chapter in the OECD Economic Survey of Ireland which was published in September 2015 under the authority of the Economic and Development Review Committee. This paper was prepared for the OECD Economic Survey of Ireland published in September 2015 under the authority of the Economic and Development Review Committee.
} 
Figure 1. Ireland's market income GINI is the highest in the OECD

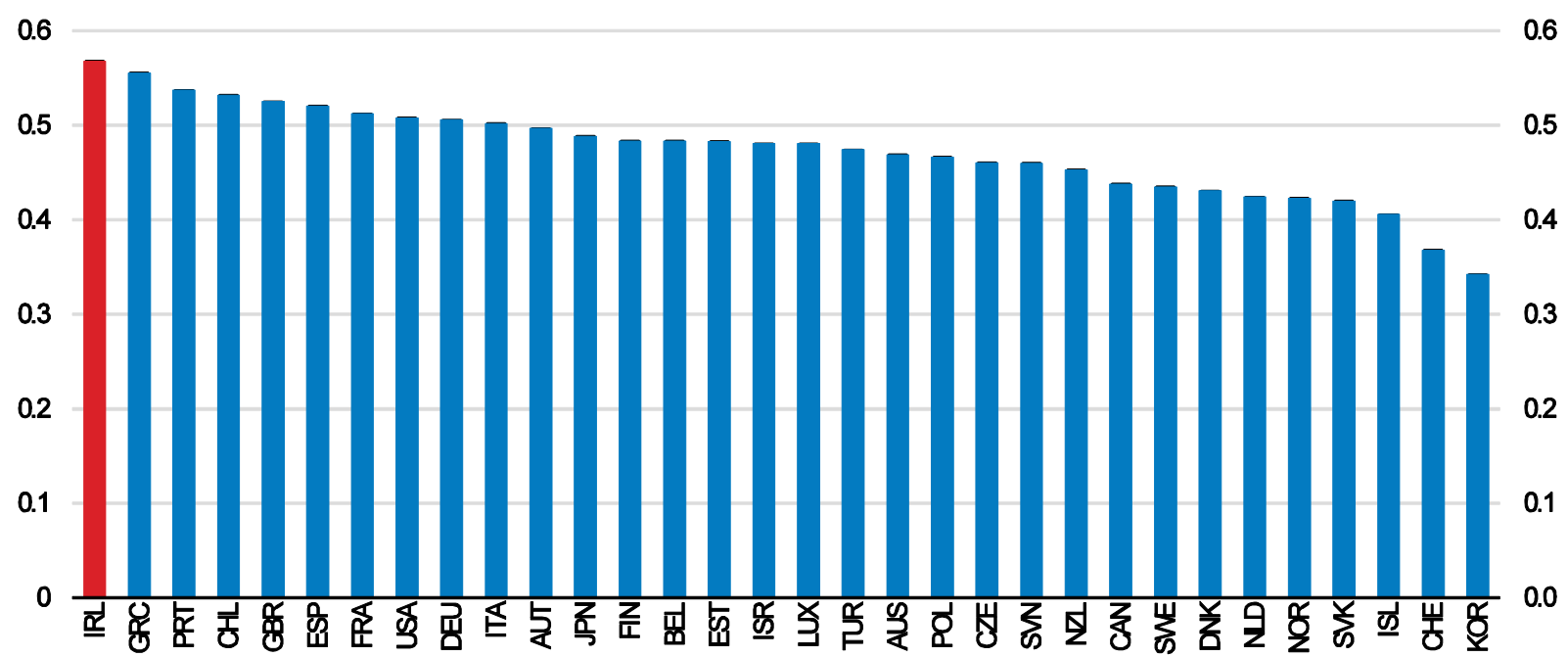

1. With $0=$ perfect equality and $1=$ perfect inequality

Source: OECD Income Distribution Database

This weakness of labour earnings at the bottom of the distribution results in income inequality being the highest in the OECD, when measured before taxes and transfers ("market incomes" GINI) (Figure 1). When taking into account taxes and transfers, however, Ireland's income inequality is below the OECD average (Figure 1.2), reflecting a tax and transfer system that is very effective in redistributing income. Indeed, the market income inequality increased markedly during the recession owing to the dramatic rise in employment losses (Figure 3). But after taxes and transfers inequality did not rise. This strong income support provided by the welfare system prevented the unemployed from falling into poverty, preserving economic and social stability.

Figure 2 Ireland's disposable income GINI is below the OECD average

0.6

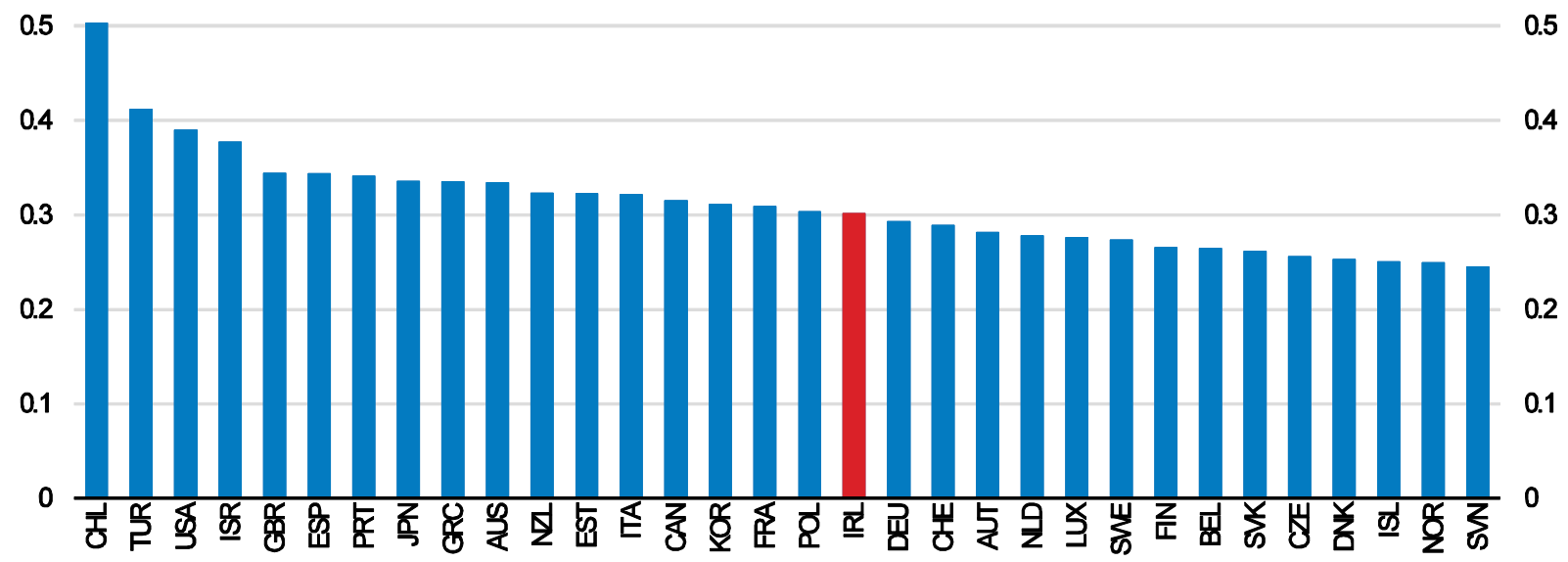

1. With $0=$ perfect equality and $1=$ perfect inequality

Source: OECD Income Distribution Database 
Figure 3 The increase in market income inequality in Ireland was largely driven by employment effects Wage and employment effects explaining change in the Gini coefficient between 2007 and 2011

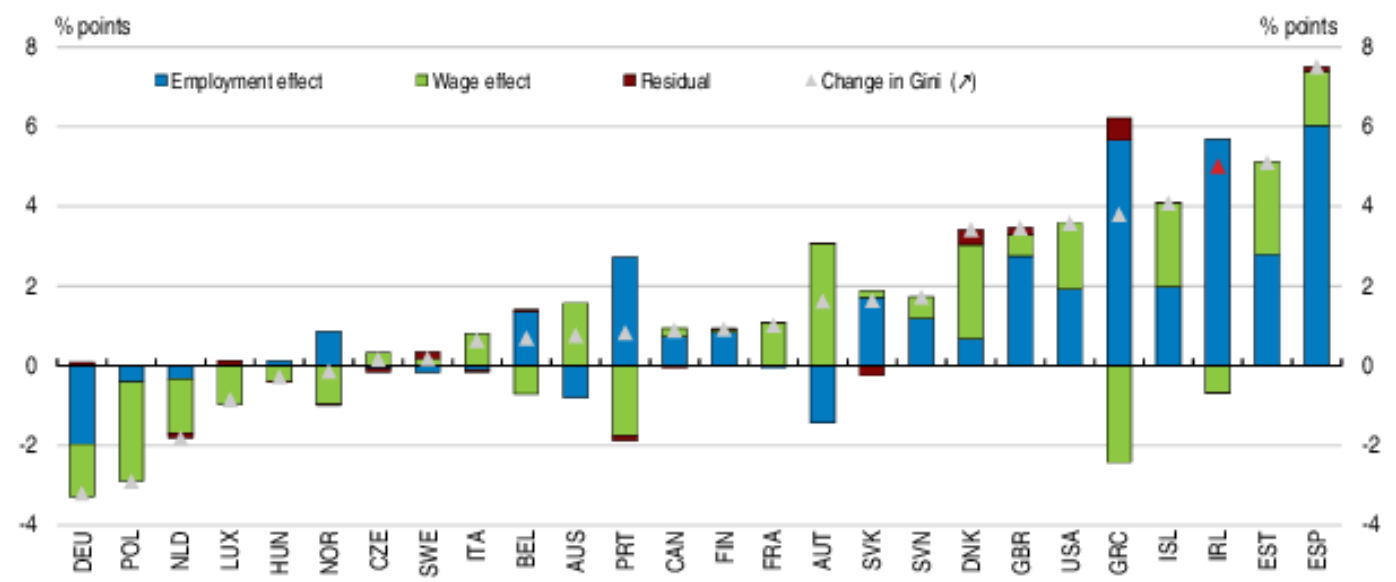

How to read this figure: The scale shows the change in the Gini index at market income between 2007 and 2011. This change is decomposed into wage and employment effects using the same method. For example, the market income inequality measured by the Gini index rose by some 5 percentage points in Ireland from 2007 to 2011, which is entirely explained by the employment effect (i.e. reduction in earnings following job separation was dominant), although the wage effect offset this very slightly (i.e. wage disparities among those in employment were reduced somewhat).

Source: OECD (2015) "In It Together: Why Less Inequality Benefits All” Chapter 3, Figure 3.2.

Indicators of income concentration directly calculated from taxpayers' income statements to the Revenue Commissioners confirms that market income inequality is high in Ireland, driven by both ends of the income distribution. Around 37\% of market income goes to the top 10\% of tax units in 2012 (of which $10.5 \%$ and $3.3 \%$ to the top $1 \%$ and the top $0.1 \%$, respectively, according to Kennedy et al., 2015). This concentration was somewhat lessened following the property bubble burst, but remains high. Nonetheless, by international comparison the concentration is not excessively high (Figure 1.4). High market income inequality is also driven by the lower end of the distribution: the income share of the bottom $20 \%$ households is the lowest in the OECD countries (Figure 5). A consequence of this is that at market incomes poverty is mostly very high. According to EU-SILC data, some $50 \%$ of individuals would live at or below the poverty line of $60 \%$ of the median disposable income, if they did not receive social transfers (Figure 6). Among those most affected by poverty are the unemployed (36.7\%) and households where there is no person at work (34.5\%). 
Figure 4 Internationally income is becoming more concentrated at the top

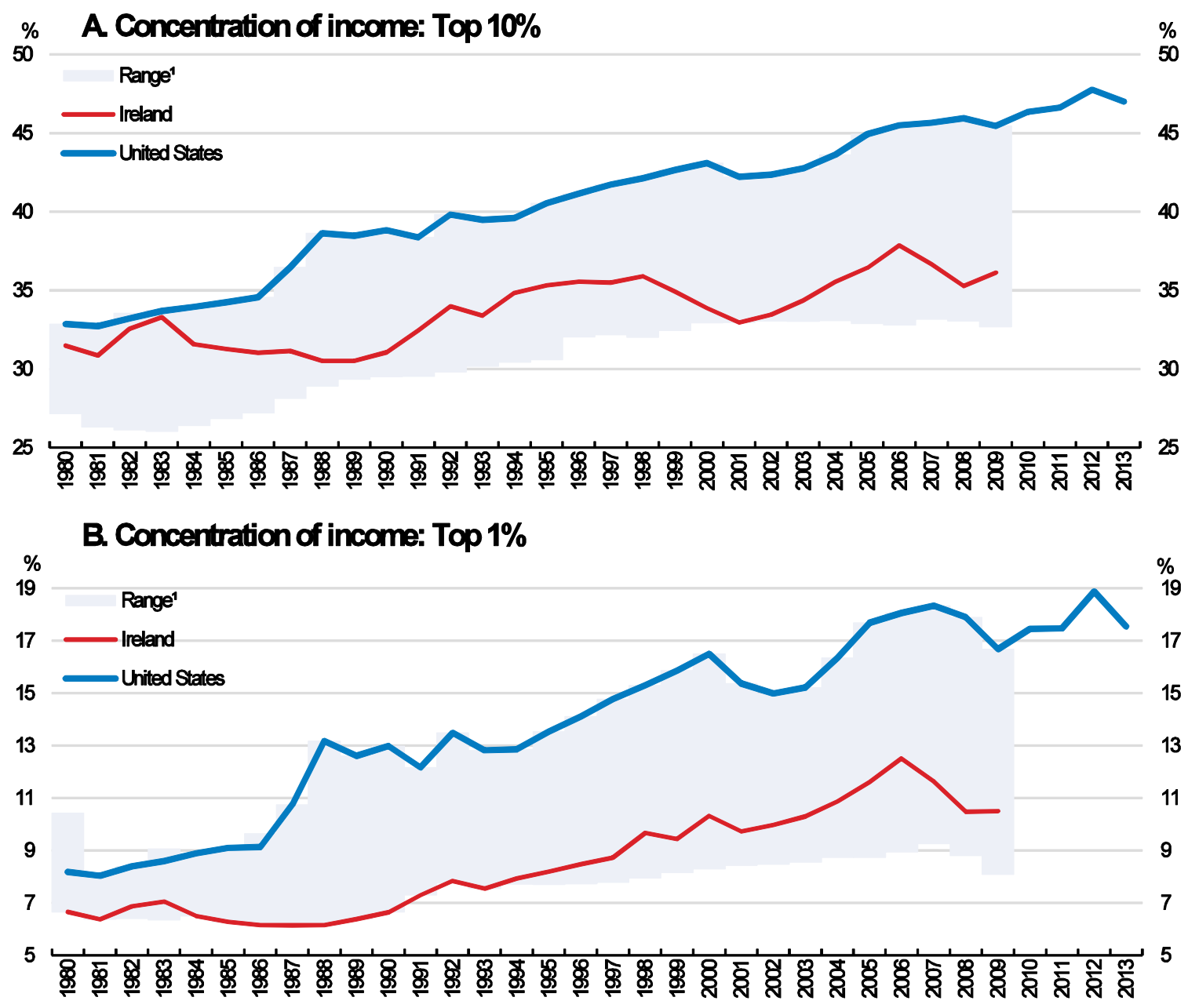

Source: Alvaredo, Facundo, Anthony B. Atkinson, Thomas Piketty and Emmanuel Saez, The World Top Incomes Database, http://topincomes.g-mond.parisschoolofeconomics.eu.

Figure 5 Share of the bottom $20 \%$ households in market income is low in Ireland

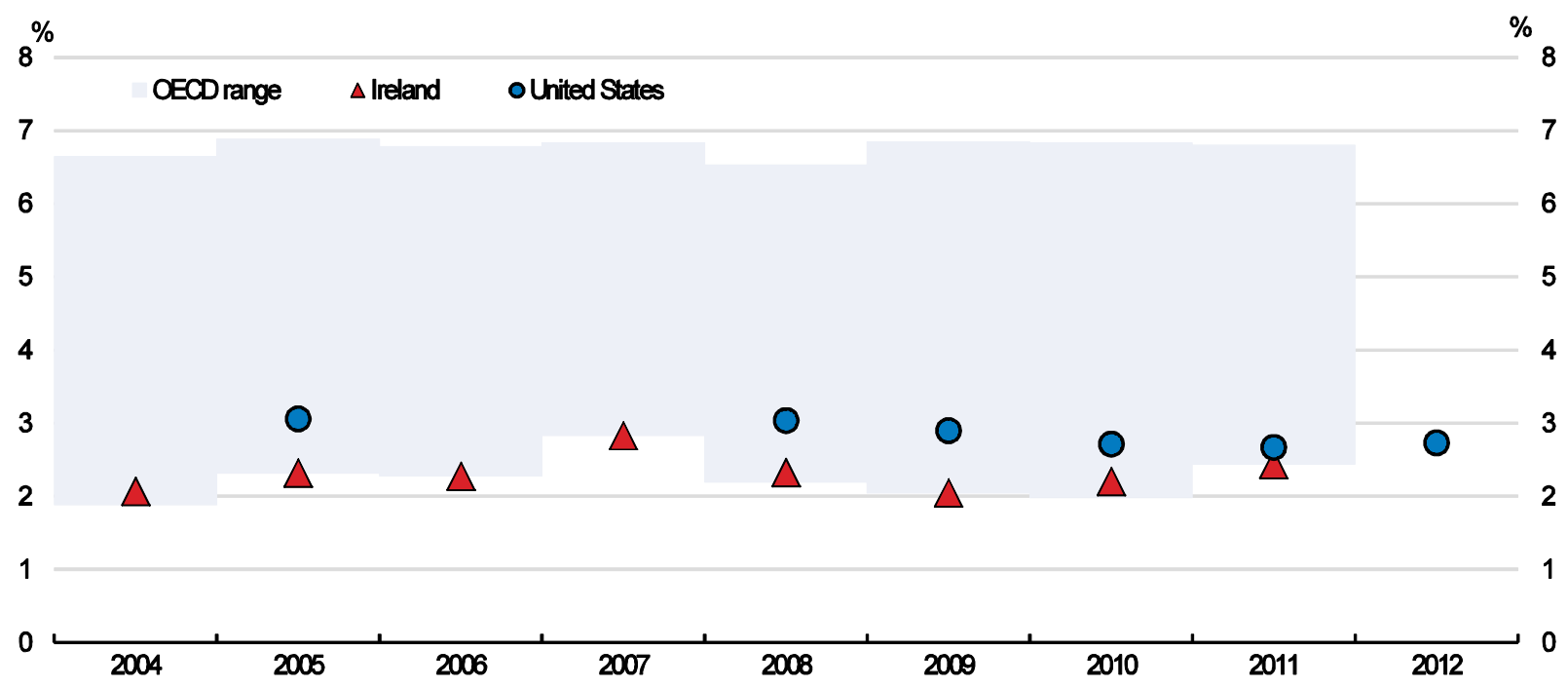


Source: OECD Secretariat's calculation from OECD Income Distribution Database.

Market income inequality is also strongly affected by macroeconomic fluctuations. During the early stages of the "Celtic tiger" period (1997-2002), all income groups experienced strong growth in market income (Kennedy et al., 2015). By contrast, when the economy entered into the property bubble (2002-07), only those at the top $9^{\text {th }}$ decile and above benefitted, reflecting fast rise in both capital income and labour earnings at the high end of the income distribution. During the burst of the property bubble (2007-12), labour earnings declined by some $14 \%$ in the aggregate, with the burden disproportionately borne by those in lower income deciles.

Figure 6 Risk of poverty is high without social transfers

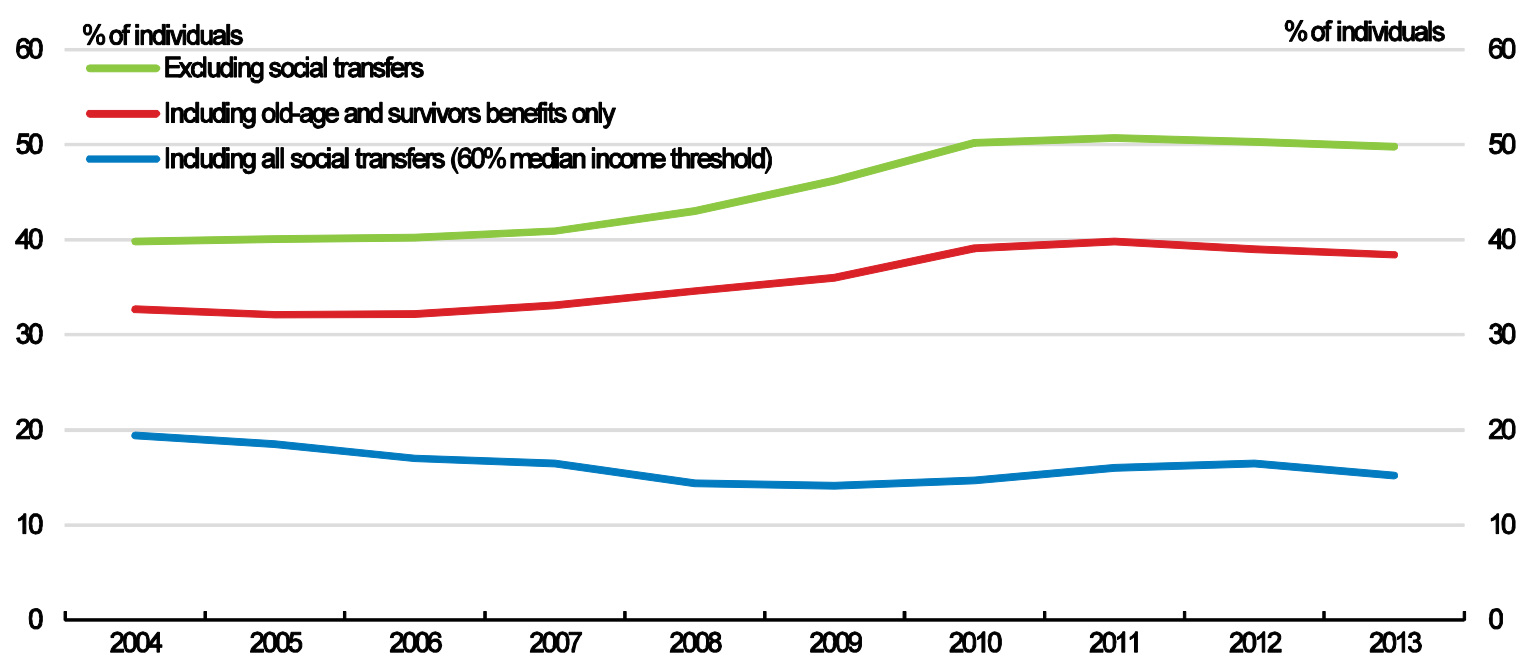

Source: Central Statistics Office, Ireland

\section{Why is there such high inequality at market incomes?}

Ireland's high inequality of market incomes largely reflects its uneven distribution of labour earnings. The ratio of the top income decile to the bottom income decile is high by OECD standards and the distribution has fatter tails than the OECD average. Higher shares of income are concentrated at the top and bottom of the income scale, while smaller shares are in the middle of the income distribution than the OECD average (Table1).

Table 1. High shares of labour earnings are concentrated at the top and bottom of the scale

\begin{tabular}{lllll}
\hline & More than & More than the median 1.5 times \\
& At or & half the & but at or the median \\
& below half & median but below 1.5 but at or & More than \\
of the & at or below & times the below twice twice the \\
& median & the median & median & the median median \\
\hline
\end{tabular}

Ireland

\begin{tabular}{lccccc} 
Below upper secondary & 40.0 & 27.8 & 17.9 & 9.5 & 4.8 \\
$\begin{array}{l}\text { Upper secondary or post-secondary non- } \\
\text { tertiary }\end{array}$ & 33.6 & 28.5 & 18.2 & 10.3 & 9.5 \\
\hline $\begin{array}{l}\text { Tertiary-type B education } \\
\text { (21.7 }\end{array}$ & 24.5 & 22.9 & 11.1 & 19.8 \\
\hline
\end{tabular}


ECO/WKP(2016)17

\begin{tabular}{|c|c|c|c|c|c|}
\hline $\begin{array}{l}\text { Tertiary-type A or advanced research } \\
\text { programmes }\end{array}$ & 13.8 & 15.4 & 14.4 & 19.3 & 37.2 \\
\hline All levels of education & 27.4 & 24.3 & 17.8 & 12.7 & 17.9 \\
\hline \multicolumn{6}{|l|}{ OECD average } \\
\hline Below upper secondary & 27.1 & 46.3 & 19.0 & 4.8 & 2.7 \\
\hline $\begin{array}{l}\text { Upper secondary or post-secondary non- } \\
\text { tertiary }\end{array}$ & 17.0 & 39.0 & 27.1 & 9.9 & 7.1 \\
\hline Tertiary-type B & 12.3 & 27.4 & 31.5 & 15.1 & 13.7 \\
\hline $\begin{array}{l}\text { Tertiary-type A or advanced research } \\
\text { programmes }\end{array}$ & 9.4 & 17.9 & 27.5 & 17.7 & 27.6 \\
\hline All levels of education & 16.0 & 34.2 & 26.3 & 11.6 & 11.9 \\
\hline
\end{tabular}

Source: Education at a Glance

This is associated with the returns to tertiary education and the penalty for poor education both being higher in Ireland than the OECD average. A high share of the workforce with tertiary education earn more than twice the median income (Figure 7, panel A). A possible contributor to this high earnings premium for tertiary education is the strong presence of multinationals, which offer highly-paid jobs to those with high skills. By contrast, those with below upper secondary education are concentrated at the bottom of the income distribution (Figure1.7, panel B). These skill-based wage differentials have important effects on the overall distribution of earnings because Ireland has a higher percentage of 25-64 year olds than the OECD average with a tertiary degree (40\% versus $33 \%$ ) and about the same share of those with below upper secondary education as the OECD average of $24 \%$. 
Figure 7 Skill-based wage differentials are high in Ireland
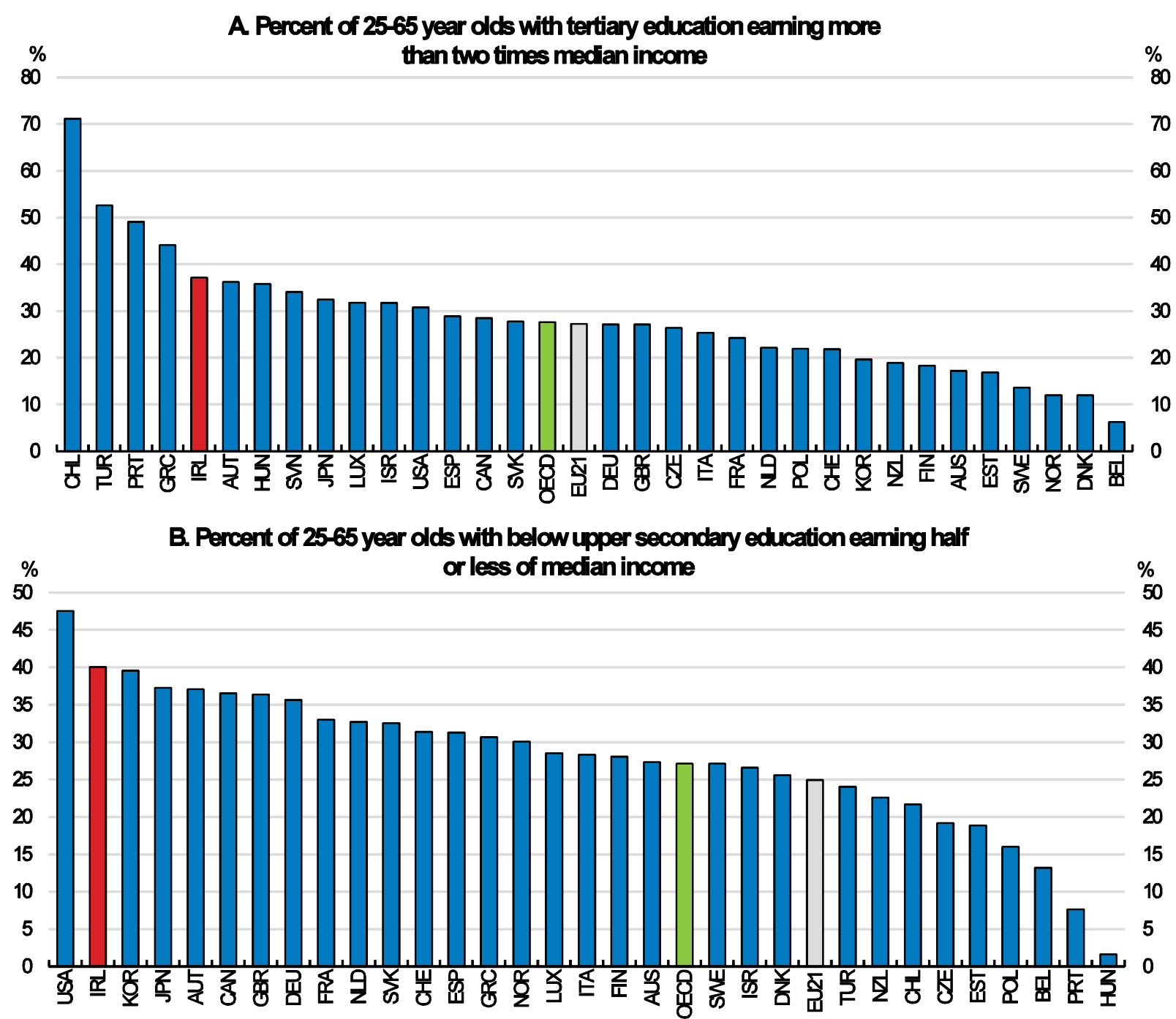

Source: Education at a Glance, 2014.

There was a significant number of jobless households before the crisis, suggesting that unemployment has been a long-standing structural problem. Moreover, among those that are employed the share working part-time is high. The share of those who are unemployed or inactive, thus with no labour earnings, is high among the low-educated (Table 2). There was a marked difference in the employment rate between the low-educated and the high-educated before the crisis and it has become larger. A regression using 30 OECD countries to explain variations in the Gini before taxes and transfers suggests that the most important factors for Ireland are the low employment ratio and the high share of the tertiary qualified with a large earnings premium, which both raise inequality.

Labour's share of national income has declined in Ireland, as it has in many other OECD countries, largely reflecting technological changes (OECD, 2012): Technological change appears to be capital-augmenting (e.g. Bentolila and Saint-Paul, 2003) or to replace routine work (Autor et al., 2003) and is biased toward high-skilled labour (Bassanini and Manfredi, 2012). Also, globalisation has raised pressures to reduce labour costs, due to increased import penetration from, and offshoring of production to, developing countries (OECD, 2007; Hijzen and Swaim, 2010; Bloom et al, 2011). Such pressures are felt 
particularly by low-skilled workers, who in effect face more competition from workers in developing countries.

Table 2 The low-educated are more likely to be jobless than the OECD average

Employment rate by educational attainment level

\begin{tabular}{lcccc}
\hline & 2000 & 2005 & 2010 & 2013 \\
\hline Ireland & & & & \\
Below upper secondary & 55.9 & 58.4 & 47.6 & 46.9 \\
Upper secondary or post-secondary non-tertiary & 76.6 & 76.7 & 66.5 & 66.0 \\
Tertiary education & 87.5 & 86.8 & 81.0 & 80.1 \\
OECD average & \multicolumn{4}{c}{} \\
Below upper secondary & 57.2 & 56.5 & 55.5 & 54.7 \\
Upper secondary or post-secondary non-tertiary & 75.1 & 74.8 & 73.8 & 73.5 \\
Tertiary education & 84.7 & 84.1 & 83.1 & 83.0 \\
\hline
\end{tabular}

Source: Education at a Glance Interim Report (OECD, 2015)

\section{How does Ireland reduce inequality?}

For Irish families with children, the tax and welfare system provides an effective system of income redistribution, as shown by the largest difference between the market and disposable income GINI coefficients in the OECD (Figure 1.1 and Figure 1.2). As a result, income inequality after tax and transfers is below the OECD median. In Ireland, a one-earner married couple with two children with market income of $50 \%$ of the gross average wage receives $85 \%$ of the average gross wage when accounting for all taxes and transfers. A similar pattern applies for single parents with two children.

The significant increase in disposable income of low-income families with children and associated decrease in inequality reflects the structure of the tax-transfer system: these families pay low or zero income taxes and social charges; and they receive significant welfare payments related to housing, child or replacement income. By international standards, Ireland provides generous social family income support. Direct child income support has three main components: Qualified Child Increases (QCIs) targeted at welfare recipients, family income supplement (FIS) targeted at low-income employees and a universal child benefit.

Social transfers are funded by a progressive tax system. Ireland's effective income tax rate, defined as the share of total income paid in taxes, is progressive (Kennedy et al., 2015). The effective income tax rate ranges from virtually zero for taxpayers in the lowest income decile to $30.9 \%$ for those in the top income decile (income tax, tax allowances and tax credits, and the Universal Social Charge are included; the Pay Related Social Insurance is excluded). The effective tax rate is $38.2 \%$ and $41.1 \%$ at the top $1 \%$ and $0.1 \%$ income groups, respectively, and the progressivity is somewhat lessened at this level. The progressivity in the Irish tax system is also confirmed by the contribution to total tax receipts of each income decile. In $2012,59.3 \%$ of income tax revenue was paid by the top $10 \%$ tax units (of which $21.3 \%$ and $7.2 \%$ for the top $1 \%$ and $0.1 \%$ tax units, respectively).

New data compiled for this Economic Survey shows that Ireland's tax and welfare system has become increasingly more supportive of low- and middle- income households. The total amount of social benefits on which tax has been paid (around $1 / 4$ of total social benefits) has risen significantly as it has been more than doubled as a percentage of disposable income over the last decade. While tax credits have become more generous for low and middle-income households, tax allowances were reduced for high-income earners. As a result, after-tax income is more evenly distributed and its share is increased up to the $8^{\text {th }}$ 
decile (transfers especially benefit the $3^{\text {rd }}$ to $6^{\text {th }}$ income deciles, while the tax system overall supports the $2^{\text {nd }}$ to $7^{\text {th }}$ ). Higher income groups bear most of the tax burden. For the top decile, the share of market income is $36.8 \%$, but $29.7 \%$ after taxes and transfers. However, the reduction in the share of income after redistribution is less pronounced for the top $1 \%$ and above.

\section{Social mobility is low at the low end of distribution}

Social mobility (the probability of individuals changing income group over time) is also an important aspect of inclusiveness. In a mobile society, households can move up (or down) relatively fast, while this is not the case in an immobile society. A high level of income inequality is of more concern if coupled with low mobility across time. From the perspective of inclusiveness, it is a particular concern if those who are at the low end of income distribution remain stuck overtime. Such immobility is very likely to arise from high incidence of long-term inactivity, possibly associated with low incentives to return to work due to welfare dependence.

New data compiled for this Economic Survey shows that about $43 \%$ of tax units remained in the same quintile income groups between 2004 and 2012 (Kennedy et al., 2015). Less mobility occurs at the low and high ends of income distribution (47\% and 58\% of tax units remained in the lowest and highest quintile groups), while mobility is more frequent in middle income classes (on average $37 \%$ of tax units remained in the same quintile group). This is similar to the United States. The mobility at the lowest end of income distribution increased during the crisis as more people crowded into that group after losing their job and main source of income (which resulted in comparative and incremental upward mobility of the rest of the population).

Wealth tends to be more unevenly distributed than income, and even more so if coupled with income immobility. There is an apparent correlation between the wealth and income distribution and wealth is particularly concentrated at the higher end of the income distribution (Table 3). The way financial assets are distributed is consistent with the fact that capital income is concentrated among the highest income groups (Kennedy et al, 2015). The factors explaining income disparity are also reflected in the wealth distribution: highly educated people tend to own more assets than the rest; the unemployed people have typically much lower wealth than those in employment (Table 3). The high level of market income inequality associated with low income mobility, if it cumulates over time, will further increase wealth disparities. This in turn may lay ground for perpetuating further disparities: those who were born in less wealthier households attain lesser degrees of education, affecting their income prospects. 
Table 3 Assets are distributed unevenly across income and socio-economic groups

Median value of wealth for each group as a share of the overall median value in the economy

\begin{tabular}{lcc}
\hline & Any Real Assets & Any Financial Assets \\
\hline Percentile of Income & 0.62 & 0.48 \\
$<20$ & 0.63 & 0.37 \\
$20-39$ & 0.94 & 0.68 \\
$40-59$ & 1.12 & 1.37 \\
$60-79$ & 1.84 & 4.92 \\
$80-100$ & & \\
Work Status of Reference & & 0.95 \\
Person & 0.97 & 4.29 \\
Employee & 2.13 & 1.90 \\
Self-employed & 1.12 & 0.16 \\
Retired & 0.50 & 0.49 \\
Unemployed & 0.88 & \\
Other & & 0.79 \\
Education of Reference Person & 0.82 & 0.67 \\
Primary education or lower & 0.93 & 0.79 \\
Lower secondary & 0.98 & 1.68 \\
Upper and post-secondary & 1.22 & 2.38 \\
\hline Third level degree and lower & 1.22 & \\
\hline Postgraduate & & \\
\hline
\end{tabular}

Note: The reported median value in each socio-economic group is the median value among the households with any assets. CSO (2015) reports data by each socio-economic group (income quintile, region, household size, educational attainment, employment status) in terms of: percentage of households owning any kind of assets (main residence, other properties, lands, deposits, equities, bonds, etc.); median value of these assets conditional on ownership (i.e. excluding the households without assets); and the share of each assets within each socio-economic group.

"Reference person" is the person who answered the survey question in each household.

Source: CSO (2015) from the results from the Household Finance and Consumption Survey 2013 which provides details of the household financial situation according to different household types, including income and wealth.

\section{Towards more inclusive growth}

Ireland needs to shore up its future growth prospects by ensuring the benefits of the recovery are spread widely. The first priority should be to get more people into better paying jobs. This requires building skills among the unemployed and continuing to improve activation policies in line with bestpractice centred on mutual obligations. The business sector has an important role to play in both these endeavours through its input into training design and providing on-the-job training opportunities as part of apprenticeship and other programmes. Ireland also needs to reduce existing disincentives to work that are built in the tax and welfare system. The system does a generally good job at supporting those on lower incomes, but a side-effect of the system is that the beneficiaries of social transfers may face high effective marginal tax rates upon return to work, or once in work when they want to increase their hours.

\section{Building skills and getting more people back into work}

An important policy implication of the labour earnings distribution is that for Ireland, even more than for most OECD countries, reducing inequality at market incomes requires lifting education levels of the most poorly educated. This requires upgrading the skills of the unemployed, particularly the long-term unemployed and preventing youth from leaving the education system under-qualified. One of the key elements in designing policies to get people back to work is conditionality (discussed further below), that is, providing benefits conditional on the recipient actively searching for work, taking an available job, or taking training (OECD, 2013a). 
Around 90000 persons, i.e. $26 \%$ of the registered unemployed, have been without a job for more than 3 years, and only $51 \%$ of single parents were in employment in 2014, compared to an EU15 average of $69 \%$; the latter gap was apparent before the crisis, indicating that it is largely structural. In addition, many workers who lost their jobs, especially men and older workers, have stopped seeking a job and withdrawn altogether from the labour market (Kelly et al, 2015). The activity rates of the low-skilled are particularly low in Ireland. Only 50\% of the individuals in the 20-30 age group are employed or are seeking work, 20 percentage points lower than in other advanced economies in the European Union.

Ireland has a markedly higher percentage of younger cohorts (25-34 years old) with tertiary qualifications than both OECD and EU averages. However, there remains a large cohort of unemployed with insufficient skills. Raising skill levels is especially important for reducing inequality at market incomes given the mentioned evidence that the reward for education and the penalty for a lack of skills are very high. These high skill premiums and penalties result from the wide gap between the skills of the workforce and the needs of employers (Figure 1.8): employers are willing to pay a premium for hard-tofind talents, but are unwilling to do so for the many with low skills. This gap is increasing: the recovery is skill-intensive and creates job opportunities mostly for high-skilled workers, exacerbating the existing situation.

\section{Figure 8 Skill mismatches are high}

\section{Percentage of workers with skill mismatches; selected OECD countries, 2011-12}

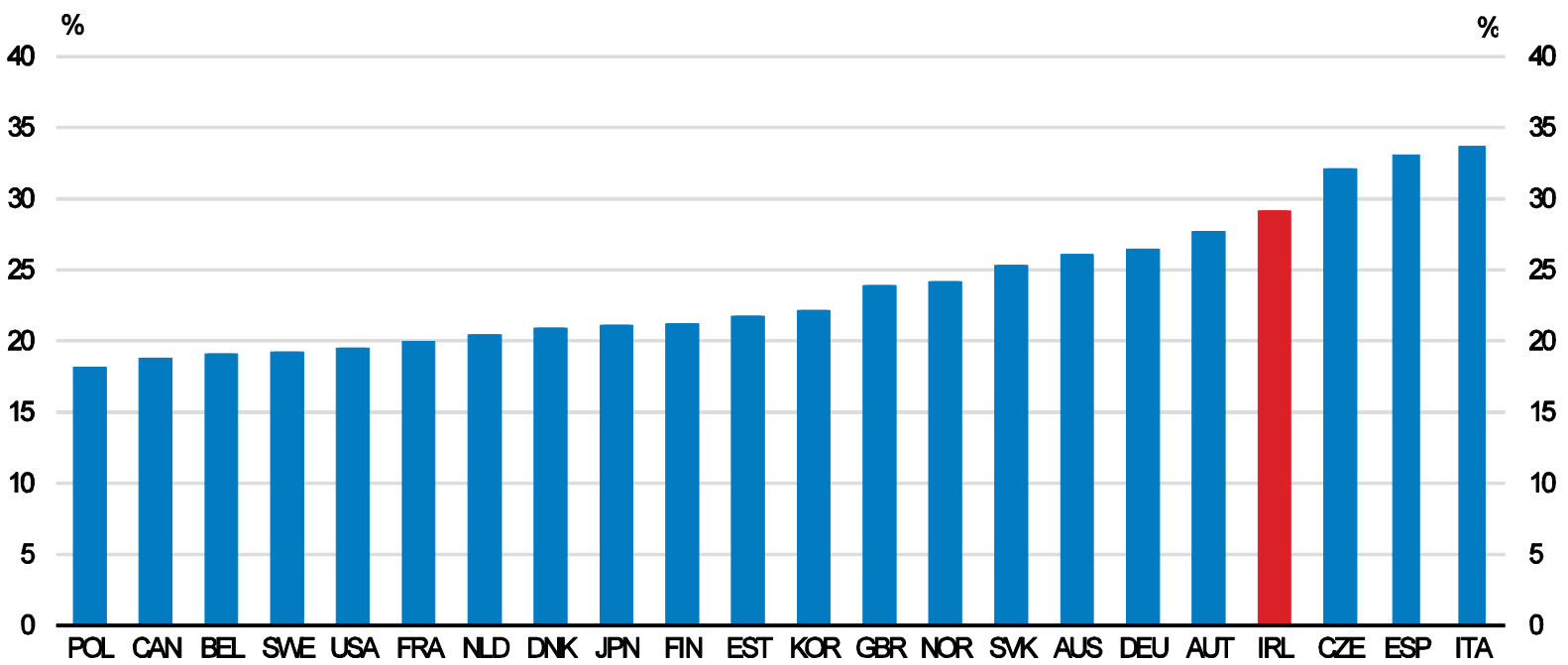

Source: Adalet-McGowan and Andrews (2015) based on OECD PIAAC data

As elsewhere in the world, Ireland has significant ICT skill gaps, with a low proportion of the population attaining good ICT skills. This ICT skills distribution translates into very large wage differentials. The salary of those with good ICT skills is more than $200 \%$ higher than the salary of those without ICT skills (OECD, 2014). This gap is one of the largest observed in the OECD. It reflects that demand for these skills is very high in Ireland. While the domestic supply of ICT graduates is ramping up, more than half of the companies that attempted to recruit ICT professionals reported difficulties finding those skills (Eurostat, 2014). Encouragingly the percentage of ICT graduates in total tertiary graduates is rising and the Department of Education has put in place an ICT action plan with the aim of further increasing the domestic supply of ICT graduates to $74 \%$ of demand by 2018 . Other occupations where supply needs to increase include engineering, science and health, as well as multilingual sales and customer care roles. 
The OECD Survey of Adult Skills (PIAAC) signals that despite improvements in recent years, Irish adults' skill level is significantly below the OECD average, and in the bottom quintile, both in numeracy and literacy skills. This relatively poor performance is partly explained by those aged 45 to 65 , who on average have relatively low levels of educational attainment. However, according to PIAAC, younger people in Ireland also compared unfavourably with their peers in other OECD countries (Figure 9). The percentage of younger adults scoring at higher proficiency levels is low in Ireland in international comparison.

Figure 9 A low proportion of adults have high-level skills

Percentage of younger and older adults scoring at PIAAC literacy proficiency Level 4 or 5 (2012)

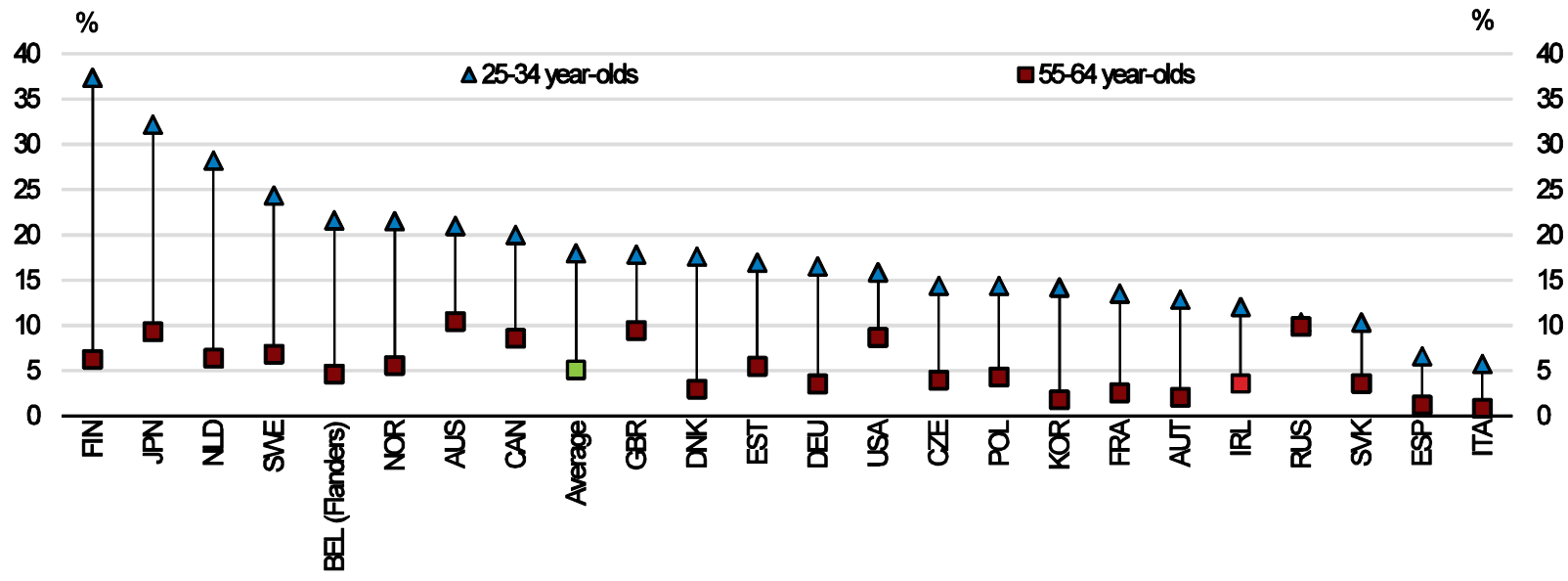

Source: OECD PIAAC, OECD (2014).

Beyond up-skilling the adult population, an equally fundamental challenge is ensuring that Irish youth acquire the skills needed to succeed in a more knowledge intensive economy. Positive developments are visible on that front. Ireland has made good progress in improving the skills of students in compulsory education as measured by PISA and has also succeeded in having a lower than average dropout rate and higher completion rates.

In tertiary education, the challenge is to ensure that skills gained in education can be efficiently transferred to the labour market. Steps have been taken to improve the alignment between the output from universities and the needs of industry, but more could be done. Improving existing information about labour market status and wages of graduates would be a useful step to provide further guidance for students. Wage information could be obtained by matching graduation and social security records. Information should encompass both university graduates and also holders of vocational and technical degrees. Providing all this information to students could be an important device to create demand-side pressure for greater labour market relevance of education programmes and could also eventually improve the reputation of vocational and technical options, which tend to have a lower social status than university studies. Ensuring that students receive appropriate information on all educational options available to them after school, including vocational and technical options, would also facilitate transitions to work and help to reduce skill mismatches.

Another important factor for Ireland becoming more skills inclusive is to minimise the impact that socio-economic status has on educational opportunities. There is evidence of social inequalities in higher education participation in Ireland. Young people from working-class backgrounds are less likely to go on 
to higher education than their middle-class peers and are also more likely to be unemployed upon leaving school. There is also evidence that the school social mix has a strong effect on educational outcomes (McCoy et al, 2014). More than 75\% of the performance differences observed between schools are explained by the socio-economic status of students and schools (OECD, 2013b). Providing disadvantaged schools with additional support, for example attracting the best teachers by paying them more or providing additional tutoring help, and making school choice policies more conducive to mixed social backgrounds would make Irish educational system more socially inclusive.

\section{Using active labour market policies to boost employment}

Activation services, including training providing participants with new and relevant skills, are crucial to boost employment prospects of the low-skilled unemployed. Progress in upgrading labour market activation policies in Ireland towards best practices in OECD countries has continued. The number of jobseekers that each caseworker in the Public Employment Services oversees on average has fallen from 800 in 2013 to 500. This is still at the higher end in international comparison and well above what is considered best practice.

The education and training system is being reformed. SOLAS, the agency in charge of overseeing the delivery of further education and the training to the unemployed, was established in October 2013. In 2014, SOLAS prepared the first ever integrated "Further Education and Training (FET) Service Plan". The plan documents the full range of FET provision and its costs. SOLAS will need to ensure that the FET programme meets the evolving needs of unemployed and of employers.

The apprenticeship system, narrowly geared towards the construction sector and hardly used by women, is also being reformed. Nevertheless, the pace of reform is very slow and lags behind the reform pace in other areas. Eight years after the start of the crisis and the construction bust, the development of the new apprenticeship system is only beginning. An apprenticeship council was established in November 2014. A call for proposals to develop apprenticeships in areas beyond construction trades, as recommended in previous Economic Surveys (for example OECD, 2011; OECD, 2013b), was issued in January 2015. Proposals were received by the end of March 2015, and the apprenticeship council will evaluate them by the end of June.

The authorities are rolling-out the JobPath initiative, whereby private providers will be in charge of activating the long-term unemployed. The actual service provision will only start in the second part of 2015. International evidence signals that, frequently, there are difficulties in implementing effectively the contracting out of activation. A successful roll-out will be crucial to avoid the current cohort of long-term unemployment becoming perpetually disenfranchised from the labour market and socially excluded.

Ireland devotes significant fiscal resources to active labour market programmes intended to assist the unemployed getting back to work by international standards (Gonzalez Pandiella, 2013). Some new programmes aimed at providing relevant skills to Ireland's increasingly knowledge-intensive economy have been launched. These programmes include Momentum (vocational education for the long-term unemployed) and Springboard (full and part-time courses in higher education for the unemployed), among others. Although such programmes are found to show good potential, they still account for a relatively low share of the overall total training envelope.

The emphasis should be thus on ensuring that those resources are channelled towards programmes and schemes that proved to be effective in helping people to gain employment. For that it is essential that evaluation mechanisms are put in place to determine what really works and, accordingly, reallocate resources towards programmes and training schemes improving employment prospects and shut down ineffective ones. Post-programme evaluation is well established across different government departments 
but there is room to make the evaluation more rigorous (see for example O'Connell, 2015 and Denny, 2015). Progress has been made in setting-up the data infrastructure to collect and link information on participants and outcomes. This information should be used to undertake timely statistical evaluation of the training programmes.

One of the few rigorous evaluations conducted in recent years that employed a control group found that some training programmes do indeed enhance the subsequent employment prospects of their participants (McGuinness et al., 2014). The study found strong employment effects for job-search skills training and medium to high level skills courses. The same study also found more modest effects for lower-level skills training, which possibly resulted from lack of policy coordination: less intensity of job search obligation and generous welfare payments (OECD, 2013a).

\section{Effective implementation of conditionality is required}

An important part of best practice active labour market policies is effectively implementing mutual obligations. Conditionality should complement adequate welfare support in order to encourage people to return to work. As the economy recovers and jobs availability increases jobseekers obligations in return for the training and other support provided by the Public Employment Service can be strictly enforced.

In the 2000s, the sanction rate for refusal of work in Ireland was close to the lowest among OECD countries, while that for insufficient job search was about $0.7 \%$ of the stock of benefit recipients - below the level for countries that required similar reporting on job-search actions (OECD, 2013a). McGuiness et al. (2011) show, with Irish data on unemployment benefit recipients, that those who do not actively commit to such activities, without effective control, encounter lower chances of entering employment.

Conditionality for unemployment benefits was tightened under "Pathways to Work" labour market reforms introduced in the early 2010s (OECD, 2013b). The percentage of beneficiaries penalised for noncompliance has increased since then. The sanction is applied gradually, beginning with a temporary reduction (around 25\%) to a suspension up to 9 weeks. The sanction rate for those who failed to attend two initial interviews with the public employment service was 3.2\% (of the inflow to the recipients) in 2014, which seems to be comparable with other OECD countries. The sanction for those who refuse to commit to active job search amounted to some 9200 cases, which is estimated to be around $3.0 \%$ of those who are registered as unemployed.

The conditionality approach can be even more enhanced in setting some objective criteria, as currently the sanction for non-compliance seems to be decided at the caseworker's discretion. For instance, the job seeker can be sanctioned when refusing a suitable job offer, against such criteria as wages, working hours, contract types, location, etc. However, it is not entirely clear how the job seeker is judged to decline a "suitable" job offer (for example, in which circumstances the job seeker has to accept a temporary contract, or what would be considered the maximum acceptable reduction of the wage compared with the previous job, etc.). The conditions do not necessarily have to be defined relative to the previous job but some objective criteria would help to motivate the job seeker/recipient of benefits to accept a job.

The provision of social benefits (other than unemployment benefits) is not now subject to conditionality in Ireland, even though many of beneficiaries could be considered fit for work. While such conditionality is not appropriate for all benefits, the authorities should consider the extent to which it could be extended. 


\section{Welfare payments and work incentives}

The Irish welfare system succeeds generally well in protecting the long-term unemployed and inactive from poverty, thus keeping income inequality near the OECD average. The overall transfer system is generous by international standards, as measured by the large decline in inequality due to transfers. In addition to allowances for jobseekers, Ireland provides a variety of welfare benefits related to housing, children and incentives to return to work.

Achieving re-distributional goals, while ensuring the tax and welfare system disincentives to work are minimised, is a tricky balancing exercise with many constraints. A key challenge is to deliver acceptable incomes for those earning no or low market income, while maintaining the incentive to work. The overall cost of the system is also a key consideration from a fiscal perspective and limits how far it is possible to go in minimising disincentive effects of the tax and welfare system -it is possible to lower disincentive effects by having slow or no (i.e. universal) abatement rates for benefits, but this is expensive.

\section{Fostering inclusive growth through fairer and more efficient welfare and taxation}

The design of the tax and welfare system directly affects incentives to work and to hire and therefore has a large bearing on employment outcomes and market income inequality. Labour taxes tend to be more harmful to growth and employment than property taxes (Johansson et al., 2008, Arnold et al. 2011). By creating a wedge between the cost to the employer and the gain to the employee they are a disincentive to hire and to supply labour, and therefore reduce employment and increase inequality. In Ireland there is potential to carry out a growth, jobs and equality enhancing shift in the tax system away from labour taxation towards property taxation as well as broadening the tax base. Ireland's high reliance on the tax and transfer system for reducing inequality means that such a shift needs to be designed carefully in order to avoid the shift being regressive.

Simulations show such a shift, if designed carefully, can be done in a progressive way that promotes growth inclusively (O'Connor et al., 2015). This requires examining micro-data based evidence of where welfare and low-income traps exist and how policy changes would affect the income and incentives of households across the income distribution. Previous work shows that relying on only a few example representative households to illustrate the effects of tax and welfare changes can be misleading (Callan et al., 2012). The following section is based on analysing the income implications and incentives facing individuals based on micro-data (household survey data) based simulations of tax and benefit policies using the Economic and Social Research Institute's (ESRI) tax-benefit SWITCH model carried out in O'Connor et al. (2015) as well as in previous literature.

\section{Reducing welfare traps}

For large parts of the population the tax and welfare system maintains a strong incentive to shift from welfare work to work. Indeed around two-thirds of the unemployed are single and therefore receive only the Job Seekers Benefit (JSB) or Job Seekers Allowance (JSA). Single individuals on both JSB and JSA tend to have low replacement rates (Savage et al., 2015).

However, there is evidence that unemployment traps do exist in Ireland for some groups, and particularly for those with a non-working partner and children (Savage et al., 2015). Around 18\% of the unemployed in receipt of a JSB or JSA have a replacement rate of $70 \%$ and above. The main causes for this are means tested child benefits (Increases for a Qualified Child, IQC), means tested payments for a non-working or low income partner (Increases for a Qualified Adult, IQA) and housing-cost-related payments. Indeed, simulations with micro data shows that $39 \%$ of the unemployed with children face a replacement rate of over 70\% compared to only 6\% of those without children (Savage et al., 2015). 
However, reducing these high replacement rates by cutting IQC and IQA payments is undesirable as it would substantially increase the depth of poverty, given that these payments are closely targeted at the lowest income households (Savage et al. (2014). An alternative is to ensure than in-work benefits at least partially compensate for the withdrawal of IQCs and IQAs. The new Back to Work Family Dividend introduced in 2015 that replaces the IQC fully in the first year of work and 50\% of the IQC in the second year is designed to help do this but the overall package of in-work benefits needs to be re-examined. These benefit types require careful design as an in-work low income supplement designed to reduce a high replacement rate can end up creating a low income trap if the abatement rate is high (Callan et al., 2012). This appears to be the case with the family income supplement (FIS) discussed below.

The rent and mortgage supplement (RMS) has also been a factor in high replacement rates (Savage et al., 2014). An important reason for this was that RMS used to be unavailable to a person working more than 30 hours a week. This problem is being tackled with the new housing assistance payment (HAP), which is replacing the rent supplement part of RMS. The legislation underpinning HAP was enacted in 2014 and it has been rolled out to circa 2300 households so far with targets to further increase households covered. HAP is a social housing support and is therefore available to households that qualify for social housing support. Eligibility for social housing support is based on income and housing need and does not depend on hours worked removing the potential barrier to move into work. To reduce the disincentive to return to work, the government should ensure all housing assistance payments depend on income rather than employment status.

\section{Reducing low income traps}

Even if someone exits unemployment to work, high METRs (percentage of an income increase absorbed by taxes, charges and benefit reductions) can act as a disincentive, creating low-income traps where someone's net monetary incentive to work more is low. The personal tax wedge is made up an income tax, and two types of social security contributions, an income levy (the Universal Social Charge, USC) and a social security contribution (the Pay-Related Social Insurance, PRSI). The latter is a paid by both employees and employers. The universal social charge is payable once annual income exceeds EUR 12000 with a maximum rate of $8 \%$ for PAYE earners and $11 \%$ for non-PAYE earners. There are only two income tax bands: $20 \%$ on incomes up to EUR 33800 (around the average wage) for single taxpayers and $40 \%$ thereafter. There are two main income tax credits, a personal income tax credit for all taxpayers in the state and a Pay As You Earn (PAYE) tax credit for salary, wage and pension earners. The result of these two credits is that no income tax is paid on incomes under EUR 16 500. They are the two most expensive tax credits (Kennedy et al., 2015). In addition there are employee social security contributions (PRSI) of 4\% that are payable from an income of EUR 18304 (for more details on the tax bands, see O'Connor et al., 2015).

On this basis Ireland maintains low average effective tax rates on the low paid by international comparison and an average effective tax rate around the OECD average for the higher paid (Figure 1.10). However, the system generates undesirable jumps in marginal effective tax rates at some points in the income distribution, even for those without children (Figure 11). At the bottom end of the income distribution the main issues are spikes in the marginal effective tax rate that occur as a taxpayer becomes liable, first for the USC at EUR 12 012, then at around EUR 16 500-18 000 (approximately 57\% of the average wage) when they become liable for income tax and then employee social security contributions. The first priority should be to reduce these spikes in marginal tax wedge, to prevent threshold impediments to supplying more labour. The spikes could be smoothed without raising the average effective tax wedge by using lower tax credits and more gradually rising income tax, USC and PRSI rates. A rough estimate of the cost of this policy based on multiplying the gain at different income deciles by the number of tax payers in each decile is EUR 300 million ( $0.16 \%$ of GDP). 
Figure 10 Average Tax Wedge is low for the low paid and close to the OECD average for the higher paid

Single person no child, 2014

$60 \%$ A. $67 \%$ of average eamings $\quad{ }_{60}^{\%}$
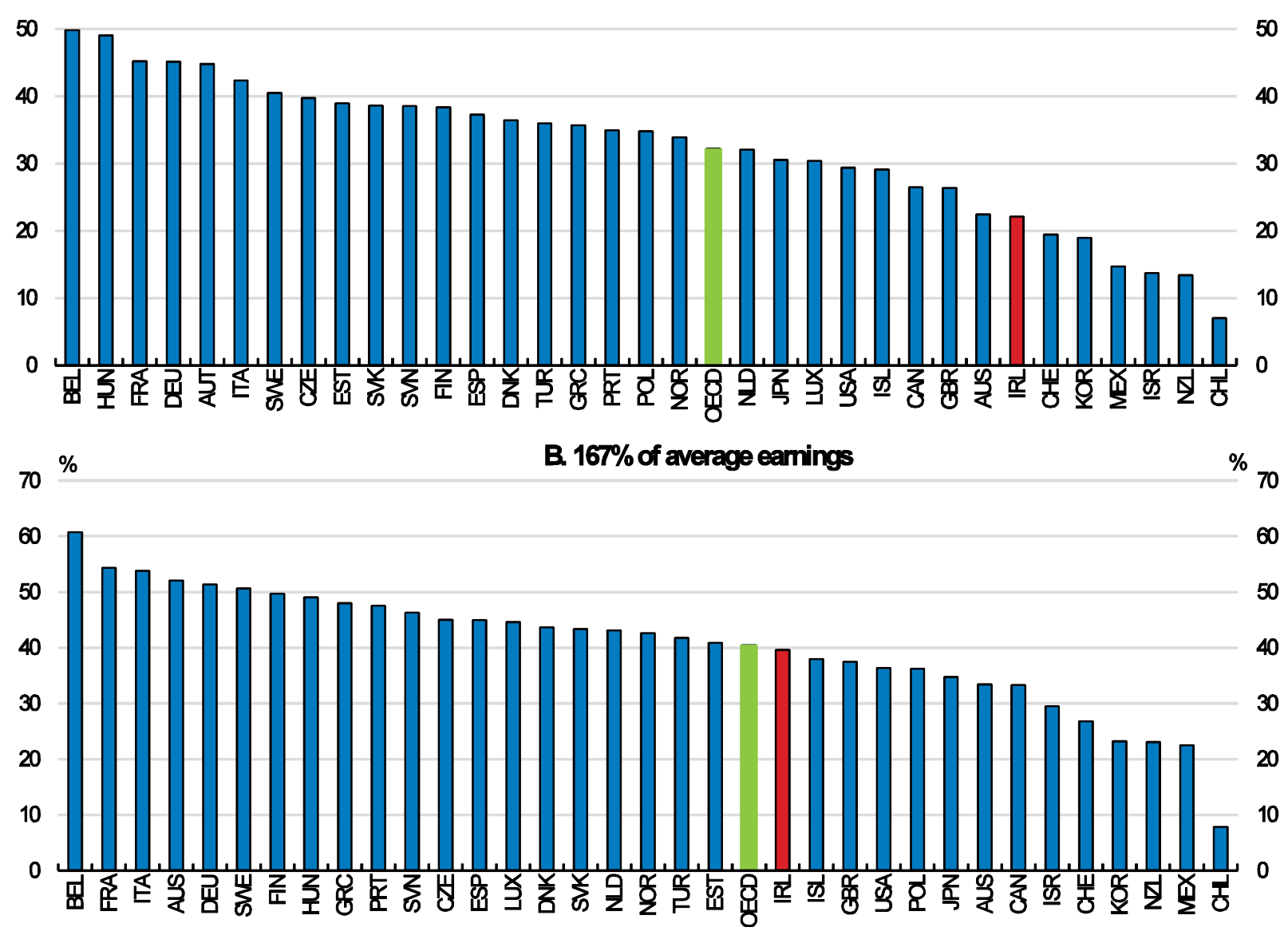

Source: OECD Taxing Wages database 
Figure 11 Some undesirable jumps in the marginal effective tax rate are built into the current system Total Marginal Effective Tax Rates 2015 (single, no children)

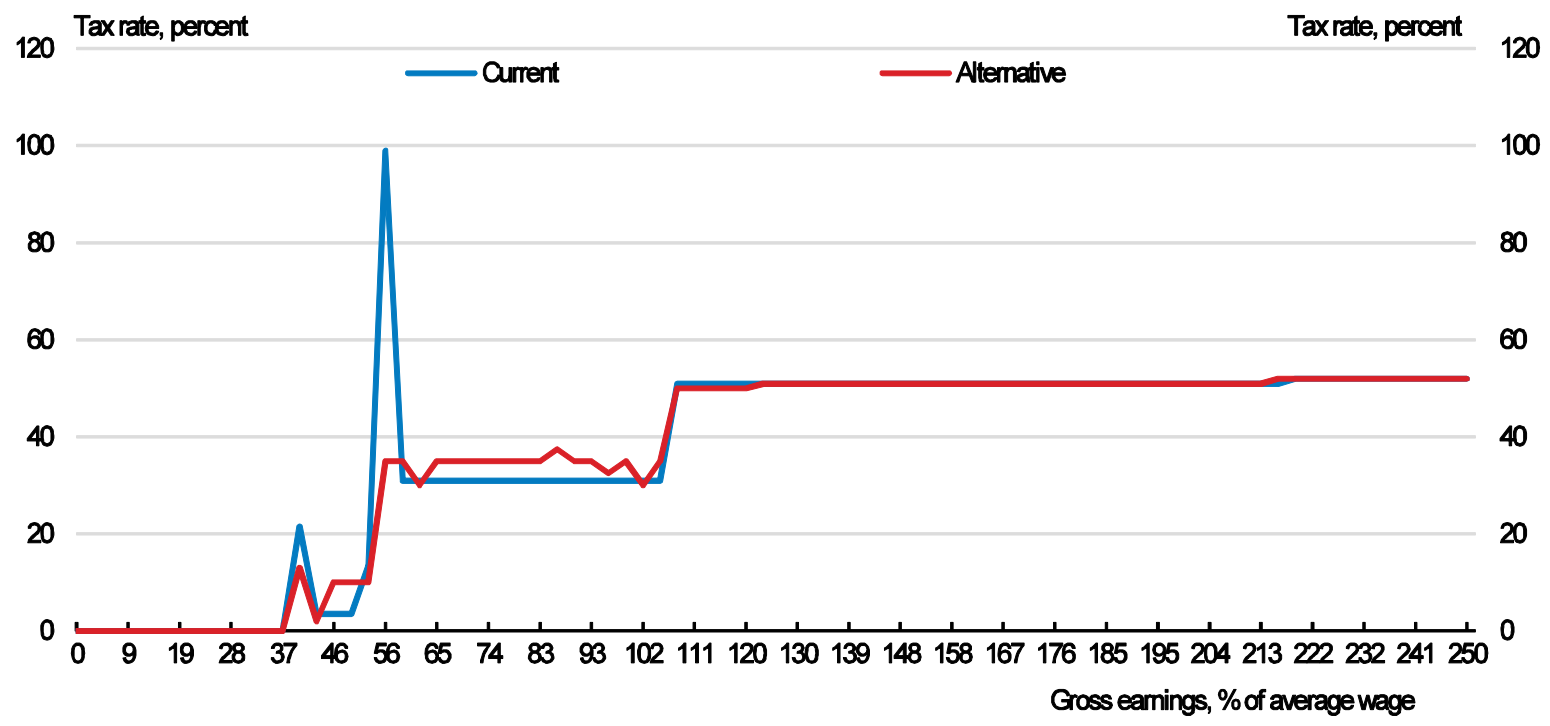

Source: OECD Taxing Wages, Revenue Commissioners and Author Calculations

In the alternative scenario, the initial tax income credits are lower and decline with income and a three band income tax band is introduced, along with lower initial USC and PRSI rates (Table 4). Almost all tax payers pay less tax on average but the overall cost is reduced by the lower income tax credits. Some taxpayers between an average wage of 60 and $100 \%$ face a marginal tax wedge that is around 3 to 4 percentage points higher than now. This could be reduced as well but the trade-off is higher fiscal cost.

Table 4 Tax Rates and Bands for PAYE taxpayers: Actual and Alternative Scenarios

\begin{tabular}{|c|c|c|}
\hline & Actual & Alternative \\
\hline Income tax rates & $\begin{array}{l}20 \% \text { on income to EUR } 33800 \text { and } 40 \% \\
\text { thereafter }\end{array}$ & $\begin{array}{l}9 \% \text { on income to EUR } 18000,20 \% \text { on } \\
\text { remainder to EUR } 33800,40 \% \text { thereafter. }\end{array}$ \\
\hline Income Tax credit & Fixed Tax credit of EUR 3300 & $\begin{array}{l}\text { Initial tax credit of EUR 1250, gradually } \\
\text { declining to } 0 \text { by income of EUR } 34000\end{array}$ \\
\hline $\begin{array}{l}\text { Universal Social } \\
\text { Charge }\end{array}$ & $\begin{array}{l}1.5 \% \text { on first EUR } 12012,3.5 \% \text { on } \\
\text { remainder to EUR } 17576,7 \% \text { thereafter to } \\
\text { EUR } 70224 \text { and } 8 \% \text { thereafter. Exempt if } \\
\text { income below EUR } 12012\end{array}$ & $\begin{array}{l}0.5 \% \text { on first EUR } 17000,1 \% \text { on remainder to } \\
\text { EUR } 27000,6 \% \text { thereafter to EUR } 39000,7 \% \\
\text { thereafter to EUR } 70224 \text { and } 8 \% \text { thereafter. } \\
\text { Exempt if income below EUR } 12012\end{array}$ \\
\hline $\begin{array}{l}\text { Pay-Related Social } \\
\text { Insurance Employee }\end{array}$ & $\begin{array}{l}4 \% \text { of gross earnings. Exempt if income } \\
\text { below EUR } 18304\end{array}$ & $\begin{array}{l}0.5 \% \text { on first EUR } 17000,4 \% \text { on remainder. } \\
\text { Exempt if income below EUR } 12012\end{array}$ \\
\hline
\end{tabular}

Source: Revenue Commissioners, Ireland.

Beyond the spikes in the METR at low wage levels generally, some lower income households with children face additional disincentives to work due to the way in-work benefits are withdrawn. The principal reason for this is the Family Income Supplement (FIS). FIS was introduced to provide an incentive to move from welfare to work (AGTSW, 2012). However, its design means that families with children may still find themselves in a low-income trap. The effective withdrawal rate (that is, the part of the marginal effective tax rate due to the withdrawal of benefits as income rises) for the low family income 
supplement is high at around $60 \%$ creating an overall marginal effective tax rate of $60-70 \%$ between 50 to $100 \%$ of the average wage (approximately EUR 16000 to 32000 per annum) (Figure 1.12).

Figure 12 Lower income households with children face additional disincentives to work

Total marginal effective tax rates 2015: Single earner couple, two children

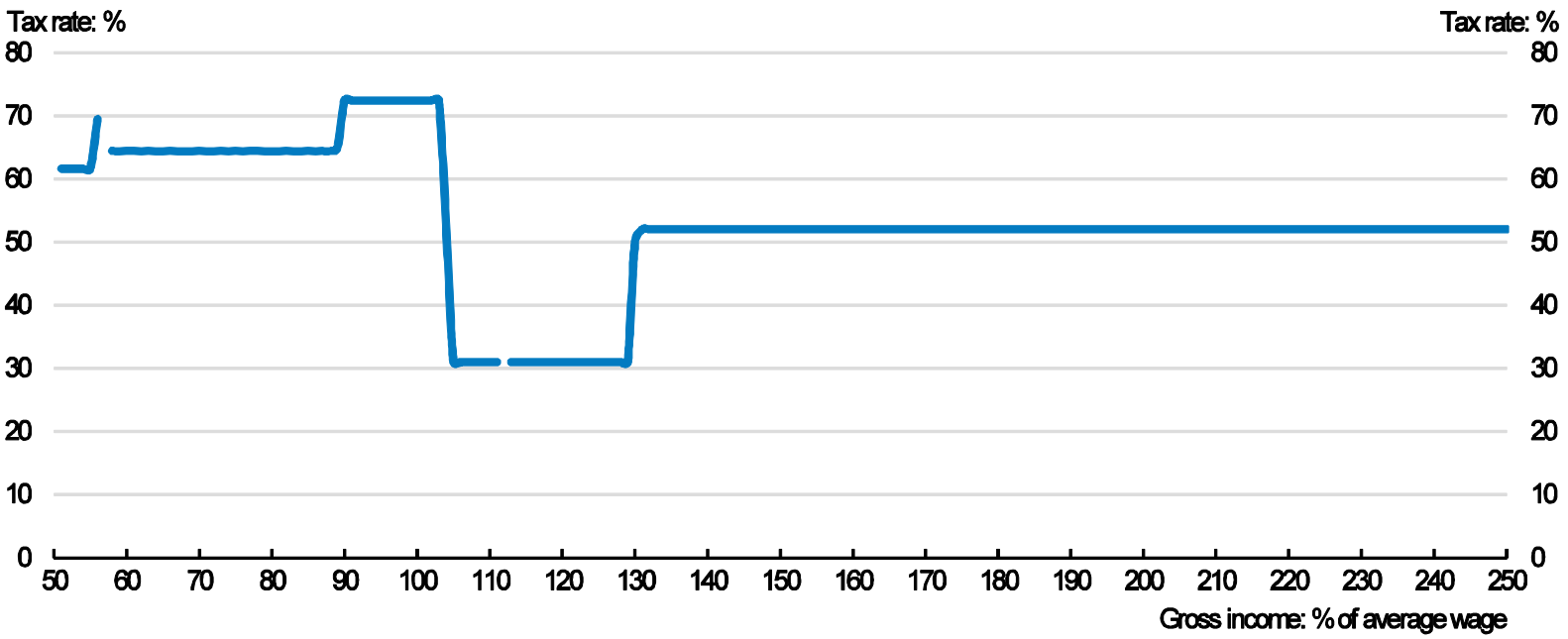

Note: The marginal tax rate is $154 \%$ at $57 \%$ of the average wage when PRSI becomes payable and $321 \%$ when the remaining EUR 1040 family income payment is removed at $112 \%$ of average wages. The tax rates include the combined effect of benefit withdrawal, income taxes, employee social security contributions and the universal social charge.

Source: OECD Tax Wages Database

To reduce the disincentive to work more for households with children, the government should redesign the low family income support supplement so that it falls more slowly with income. A possible benchmark is that it never exceeds the top marginal tax rate faced by high income earners. Simulation work using the ESRI SWITCH model suggests that reducing the FIS withdrawal rate from 60 to $32 \%$ and increasing the FIS income limits from EUR 602 to EUR 865 for a family with two children could raise disposable income in deciles 1 to 6 , in some deciles by around 1 percentage points. This is estimated to cost approximately EUR 200 million ( $0.1 \%$ of GDP) at current take-up rates of 33\%. If the take-up rate increased to $100 \%$, the reform would cost approximately EUR 700 million ( $0.4 \%$ of GDP). It should also be acknowledged that, while this reform would lower METRs for the low paid, it would create higher METRs of those further up the income distribution (Table 1.5, O'Connor et al., 2015). However, this would bring the pattern more in line with the basic progressive nature of the Irish income tax system where METRs increase with income. A reform of the FIS payments should also try to reduce the large spike in the METR around $112 \%$ of the average due to the sudden withdrawal of the last EUR 1040 of the FIS payment at that wage level. This could be done with two or more smaller steps down. A completely smooth withdrawal and METR would likely be too expensive. 
Table 5 The marginal effective tax rate for the low paid can be reduced by changing in-work benefits

Family Income Supplement - Distribution of change in marginal effective tax rates

Number of People in population ('000s) at Base Policy by Change in METR

\begin{tabular}{lrrrr}
\hline & \multicolumn{4}{c}{ Change in METR } \\
\multicolumn{1}{c}{ Original METR } & $\leq-20$ & $>-20, \leq-10$ & $>10, \leq 20$ & $>>20$ \\
\hline$<=20$ & 0.00 & 0.00 & 0.00 & $* *$ \\
$>20,<=30$ & 0.00 & 0.00 & $* *$ \\
$>30,<=40$ & 0.00 & 0.00 & 16.86 & 10.77 \\
$>40,<=50$ & 0.00 & 0.00 & $* *$ & $* *$ \\
$>50,<=60$ & 0.00 & 0.00 & $* *$ & 0.00 \\
$>60,<=70$ & 11.88 & $* *$ & 0.00 & 0.00 \\
$>70,<=80$ & $* *$ & $* *$ & 0.00 & 0.00 \\
$>80,<=90$ & $* *$ & 12.42 & 0.00 & 0.00 \\
$>90,<=100$ & 0.00 & $* *$ & 0.00 & 0.00 \\
$>100$ & $* *$ & 0.00 & 0.00 & 0.00 \\
Total & 20.41 & 17.47 & 19.92 & 22.71 \\
\hline
\end{tabular}

How to read this table: Due to the reduced withdrawal rates in the reform 11,880 people with a marginal effective tax rates between $60 \%$ and $70 \%$ experienced a reduction in their METR of more than $20 \%$.

Note: Not all taxpayers shown. Most (1.7 million out 1.8 million) see practically no change in their METR (i.e. it is between -0.5 and $0.5 \%$ different. 34000 taxpayers experience a shift of between -10 and $10 \%$ in their METR.

Data for cells with low entries have been removed for data confidentiality reasons

Source: O'Connor et al. (2015)

\section{Raising revenue more efficiently: Personal capital taxes}

Personal capital income tax rates in Ireland have been increased significantly post-crisis. The tax rate on interest in deposit accounts has increased from $20 \%$ in 2008 to $41 \%$ in 2015 and capital gains tax from $20 \%$ in 2008 to $33 \%$ in 2015 . Taking a medium-term perspective and assuming a nominal rate of return of $4 \%$ and an inflation rate of $2 \%$, the current rates of income taxes imply high tax rates on real returns. For taxpayers facing the marginal income tax rate of $40 \%$, which would account for most of those with capital income of any note, the tax rate on real income returns is around $80 \%$ and capital gains is $66 \%$ (Table 1.6), leaving very little room to increase further marginal nominal tax rates without causing real after tax returns to go negative. 
Table 6 Taxation is not neutral across different asset classes

Tax treatment of asset classes 2015

\begin{tabular}{|c|c|c|c|}
\hline Asset Class & Income taxes & Wealth taxes & Effective tax rate on real return \\
\hline Interest-bearing accounts & $40 \%$ & $0 \%$ & $82 \%$ \\
\hline $\begin{array}{l}\text { Fixed interest securities (bills } \\
\text { and bonds) }\end{array}$ & $\begin{array}{l}\text { Interest payments subject to } \\
\text { income tax rate } 20 \% \text { or } 40 \% \text {. } \\
\text { Capital gains tax } 33 \% \text {. }\end{array}$ & $0 \%$ & $\begin{array}{l}40 \% \text { or } 80 \% \text { on interest } \\
\text { payments. } 66 \% \text { on capital } \\
\text { gains. } 0 \% \text { on both interest and } \\
\text { capital gains on Irish } \\
\text { government bonds. }\end{array}$ \\
\hline Shares & $\begin{array}{l}\text { Tax at income tax rate, } 20 \% \\
\text { or } 40 \% .33 \% \text { tax on capital } \\
\text { gains. }\end{array}$ & $0 \%$ & $\begin{array}{l}\text { Dividends: } 40 \% \text { or } 80 \% \text {. Capital } \\
\text { gains: } 66 \% \text {. }\end{array}$ \\
\hline Owner-occupied housing & $\begin{array}{l}0 \% \text { on imputed rent. Personal } \\
\text { private residence exempt from } \\
\text { capital gains tax. }\end{array}$ & $\begin{array}{l}\text { Recurrent property tax } \\
\text { of } 0.18 \% \text { of the value of } \\
\text { a property up to } \\
\text { EUR } 1 \text { million and } \\
0.25 \% \text { on the value } \\
\text { above EUR } 1 \text { million. }\end{array}$ & $\begin{array}{l}9 \% \text { on properties up to } \\
\text { EUR } 1 \text { million and } 13 \% \text { on } \\
\text { value of property over } \\
\text { EUR } 1 \text { million. }\end{array}$ \\
\hline Rental housing & $\begin{array}{l}\text { Rental income at income tax } \\
\text { rate of } 20 \% \text { or } 40 \% .33 \% \text { tax } \\
\text { on capital gains. }\end{array}$ & $\begin{array}{l}\text { Recurrent property tax } \\
\text { of } 0.18 \% \text { of the value of } \\
\text { a property up to } \\
\text { EUR } 1 \text { million and } \\
0.25 \% \text { on the value } \\
\text { above EUR } 1 \text { million. }\end{array}$ & $\begin{array}{l}\text { Rents: } 49 \% \text { or } 89 \% \text { on } \\
\text { properties up EUR } 1 \text { million. } \\
\text { Capital gains : } 66 \% \text {. }\end{array}$ \\
\hline Private Pension Accounts & $\begin{array}{l}\text { Tax relief on contributions } \\
\text { between } 15 \% \text { and } 40 \% \text { of } \\
\text { earnings up to a limit } \\
\text { depending on age. Lump-sum } \\
\text { at retirement up to } \\
\text { EUR } 200000 \text { exempt, from } \\
\text { EUR } 200000 \text { - } € 500000 \text {, } \\
20 \% \text { over EUR } 500000 \\
\text { marginal income tax rate, } \\
20 \% \text { or } 40 \% \text { Cash income } \\
\text { taxed at marginal income tax } \\
\text { rate. }\end{array}$ & $\begin{array}{l}0.15 \% \text { on value of } \\
\text { assets. }\end{array}$ & $\begin{array}{l}\text { Wealth tax and income tax: } \\
48 \% \text { or } 88 \% \text {. }\end{array}$ \\
\hline
\end{tabular}

1. The temporary pension fund stamp duty levy was introduced in 2011 at a rate of $0.6 \%$ on funded pension scheme/plan assets. The original $0.6 \%$ levy applied for 4 years from 2011 to 2014 and ended last year. An additional levy of $0.15 \%$ was introduced in 2014 and 2015 . The $0.15 \%$ levy ends in 2015 . Liability for payment of the levy rests with trustees of the funds,

2. These calculations assume a real rate of return before tax of $2 \%$ but the effective tax rates would be lower at higher before tax real rates of return. This calculation does not take account of the tax relief on pension contributions and exemptions from tax for lumpsums.

Source: Revenue Commissioners, Ireland and OECD calculations.

The main exception to these high real rates is investing in your own home. For owner-occupied housing, imputed rental income and capital gains, are exempt from tax, leaving the recurrent property tax, which is equivalent to real tax rate of $9 \%$ on capital income for properties worth less than EUR 1 million. One way to decrease the investment bias would be to increase the recurrent property tax further (discussed below). However, a higher property tax combined with income taxation on rents could result in negative real returns for landlords, suggesting that further increases to property tax might need to be restricted to non-rental properties.

Although there is little headroom to increase other capital income marginal tax rates, there seems to be scope to broaden the base for taxation of capital income. Reducing capital income related exemptions would mainly affect the very highest income bracket as around $60 \%$ of capital income goes to the top $10 \%$ of tax payers, and $30 \%$ to the top $1 \%$ of tax payers (Kennedy et al., 2015). The Superannuation related exemptions are costly. They have been reduced in recent years but they could be reduced further, 
especially given tax incentives on savings instruments tend to cause substitution from one instrument to another rather than an increase in savings (Engen et al., 1996; Attanasio et al., 2004; Chetty et al., 2012). This would help to improve investment neutrality as well as raising revenue in a way that puts the largest share of the burden on the highest income brackets.

\section{Property Taxes}

As discussed above taxation treatment of property income is more favourable than other sources of capital income in Ireland. This distorts investment decisions and all else equal this will lead to over-investment in property. The first approach best is the taxation of homeowner imputed rental income, with deductions of inputs necessary to produce home services, including interest, which makes it neutral with respect to other investments as well as in terms of financing (Denk, 2012). One way to do this is through recurrent property taxes, which can be thought of as a tax on the flow of housing services on the assumption that this flow is proportional to the value of the real estate. Recurrent property taxes are more growth friendly than labour taxes, and are preferable to property transactions taxes in that transactions taxes tend to reduce mobility.

Ireland recently reduced property related transaction taxes (stamp duty was reduced from $9 \%$ to $1 \%$ on the value of a property up to EUR 1 million and $2 \%$ on the value above) and imposed a recurrent property tax (the local property tax, LPT) from 2013. The LPT is imposed as percentage of the value of the property, which is preferable from an equity point of view than the previous flat rate tax charged in 2012 (OECD, 2013b). The LPT raises approximately $0.3 \%$ of GDP, which is low by international standards in 2013 (Figure 1.13).

Figure 13 Taxes on Property are low by international standards

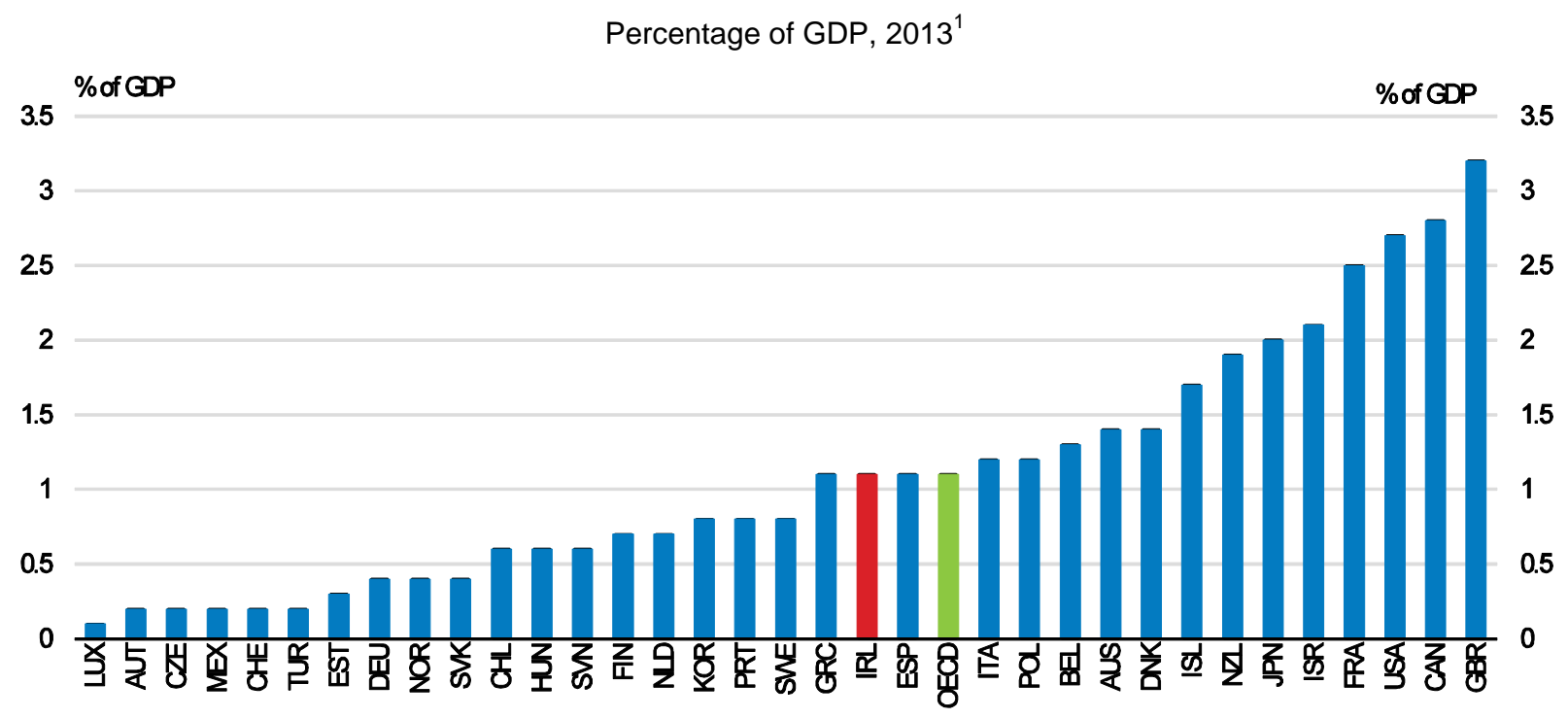

1. Or nearest year

Source: OECD Revenue Statistics

The LPT tax appears to be relatively easy to administer. The compliance rate is estimated at $96 \%$ and no-compliance results in a charge being imposed on the property. It is imposed on self-assessed valuations based on guidance from the Revenue Commissioners, who can query and impose a valuation change if they consider the self-assessment is unjustified. Valuations are carried out every three years and in the absence of any policy changes the next valuation will likely see significant increase in LPT revenues. The 
LPT is currently levied on housing values at 1 May 2013. For the period 2017 to 2019 they will be based on valuations at 1 November 2016, which will likely be substantially higher given recent price movements. House prices have already risen between May 2013 and January 2015 by 12\% and 38\% outside Dublin and in Dublin respectively. The potential impact of home price increases on the LPT yield is currently the subject of an independent review.

From an inclusiveness point of view, the tax has some progressivity built into it, with a rate of $0.18 \%$ levied on all residential properties valued up to EUR 1 million and $0.25 \%$ imposed on any remainder of the value of the property exceeding EUR 1 million. However, the overall effect of the tax is moderately regressive, with the lowest deciles paying a higher percentage of their income in LPT (Keane et al., 2012; O'Connor et al., 2015). This is because housing ownership is quite high even in the lowest income quintile.

Simulations using the ESRI's tax-benefit model show that more revenue could be raised from the LPT, while also increasing its progressivity, by raising the LPT rate steadily with housing value and simultaneously granting a low-income waiver with marginal relief (O'Connor et al., 2015). The low income waiver would exempt those on modest incomes from the LPT entirely, which has the potential to create a poverty trap at the threshold. However, marginal relief limits the LPT liability to the minimum of the LPT liability or the difference between the waiver limit and the individual's income times the marginal relief rate. Marginal relief would ensure that individual's do not face an extremely high METR when they cross the low-income threshold.

Only a modest rise in the LPT rate may be needed to generate a substantial increase in revenues from 2017 given rapidly rising house prices. Regularly updating the valuations is important to maintain public acceptance that the tax is fair (Keane et al., 2012) and the LPT should remain directly linked to property values. However, given the sharp upward movement in house prices and the implied large step jump in LPT in 2017, consideration should be given to phasing in the increase in the LPT over more than one year.

\section{Value Added Tax}

Value-added tax (VAT) accounted for $27 \%$ of tax revenues in 2014. The standard VAT rate of $23 \%$ is high by OECD standards but the revenue base is relatively narrow (Figure 1.14) due to four reduced tax rates put in place to lessen the impact of VAT on the poor and promote social and cultural goals and support the tourism industry and employment. A rate of $0 \%$ applies to food and drink and children clothing, $4.8 \%$ rate applies to livestock including horses and greyhounds, and $13.5 \%$ applies to some fuels, building services, maintenance and cleaning and in 2011 this was reduced to 9\% for tourism related services such as hotels and restaurants. Reducing labour taxes and raising more revenue from this source, especially by broadening the base, would improve the growth friendliness of the tax system and reduces distortions to consumption decisions induced by a multi-rate VAT system. 
Figure 14 The standard VAT rate is high but the revenue base is narrow

VAT Revenue Ratio, 2011

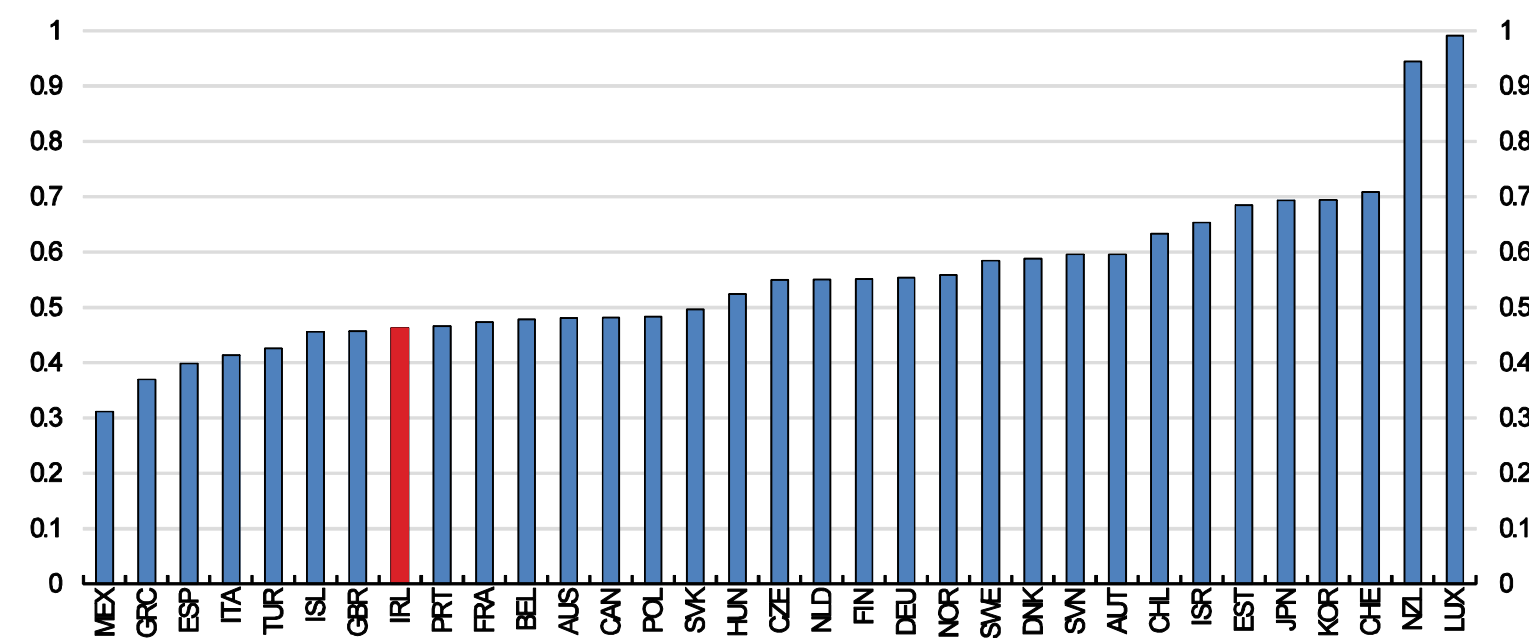

Note: The VAT revenue ratio (VRR) is defined as the ratio between the actual value added tax (VAT) revenue collected and the revenue that would theoretically be raised if VAT was applied at the standard rate to all final consumption. This ratio gives an indication of the efficiency of the VAT regime in a country compared to a standard norm. It is calculated as: VRR = VAT revenue / ([consumption - VAT revenue] $\mathrm{x}$ standard VAT rate). Consumption is final consumption expenditure from the national accounts (heading P3).

Source: OECD (2014) Consumption Tax Trends

Reforms of this nature are opposed in Ireland, as elsewhere, on the grounds that raising either the standard or reduced VAT rates would be regressive. However, the tax expenditure from these reduced rates is substantial begging the question of whether these rates are efficient in achieving their distributional and other goals given the opportunity cost of significant revenue foregone. New micro-simulation analysis by the OECD of the distributional impact of reduced VAT rates in Ireland measured by the tax expenditure received by households in each income decile shows they are untargeted and are not an efficient way to assist the poor because the rich capture a large part of the benefits in absolute terms. The overall benefit from reduced rates for top income decile households is on average EUR 1759, while bottom income decile households benefit, on average, by only EUR 973 (Thomas, 2015). Overall it would be fiscally cheaper to eliminate the reduced rates and support the poor by transferring this latter sum to low income deciles via welfare and earned income tax credits, saving the tax expenditure currently enjoyed by higher income deciles.

Beyond efficiency there is also an issue of whether the rates are effective in improving the progressivity of the tax system. In Ireland reduced rates on food, pharmaceuticals, children's clothes and energy are progressive in the sense that the poor benefit more, in proportion to their income, from them than the rich (Thomas, 2015). However, others, particularly those on restaurant meals and accommodation, are regressive because high-income households spend far more on restaurants and hotels than low-income households (Thomas, 2015).

The low rates on accommodation and restaurants were partly in place with the goal of boosting employment in the labour-intensive tourism industry. Indeed reducing the rate on these services from $13.5 \%$ to $9 \%$ was an important measure of the government's Jobs Initiative policy in 2011 estimated to cost EUR 350 million. Whether or not this was effective is controversial. On the one hand, lower VAT rates appear to have been partially passed on in lower prices and employment appeared to grow faster in restaurant and accommodation and food services than the rest of the service sector following the 
introduction of the reduced rate (O'Connor, 2013). On the other hand, most of the growth in tourism numbers in 2011 occurred before the introduction of the rate reduction, changes in tourism market share in the UK and US markets appear to be correlated with other events and the price changes induced by the VAT rate change (around 2\%) are small in comparison with exchange rate movements (Public Policy, 2013). They are also swamped by the general downward trend in accommodation prices induced by the crisis. Even if somewhat effective the recovery in the economy and labour market means the necessity of expensive measures such as the reduced $9 \%$ rate on tourism services should be reconsidered. Boosting low-skilled employment could be more effectively achieved by directly lowering hiring costs by reducing social charges or raising direct employment subsidies.

\section{A more inclusive business sector}

For two decades prior to the financial crisis, the wage bargaining system in Ireland was characterised as centralised and well-coordinated. Such a bargaining system is known for being efficient, allowing macroeconomic effects of wage settlement to be taken into account (OECD, 2012).McGuinness et al. (2008) show that in Ireland centrally negotiated wages were efficient in reducing excessive cost pressures. However, the system was not faultless. In the Irish context, the representativeness of trade unions at each establishment was problematic since there was no established rule on the recognition of trade unions: if there was no representative union within an establishment collectively agreed terms were not binding. Multi-national companies (MNCs), which have multiple establishments, found these complications particularly problematic, leading to a general avoidance of unions (Lamare et al., 2009). In general, the centralised approach is not quick enough to respond to changes in the international environment, which makes it unsuited for Ireland given its extremely high trade-to-GDP ratio. Ireland's centralised bargaining system broke down in late 2009 precisely because the largest business association refused to implement a wage agreement specifying an increase, which had been concluded in the previous year, at the height of the crisis.

Since the breakdown of the centralised bargaining system, wage negotiations take place at firm level. The firm-level negotiation system is known to be efficient in terms of flexible wage adjustments (OECD, 2012), as this enables firms to take into account firm-specific situations such as productivity. The swift labour cost adjustment following the crisis in Ireland was remarkable compared with other financiallyconstrained countries. The labour cost adjustment was likely facilitated by this wage setting framework, enabling the Irish economy to restore its competitiveness. Overall, the current wage setting system appears to be flexible enough to maintain cost competitiveness in the aggregate. However, wages negotiated at firm level are known to be more dispersed across different workers, which may aggravate income inequality. Indeed, returns to skills are likely to be more differentiated in the firm-level wage setting system (Dahl et al., 2011).

Lower income workers are partially protected by the minimum wage, which is the fourth highest in the OECD (hourly minimum wages after taxes in US dollars at purchasing power parities) for which data is available (OECD, 2015a). It was introduced in 2000 and its immediate effect was to raise the wage rate toward the lower end of the income distribution (Nolan et al., 2012). Although the minimum wage protects low-income workers, a balance must be struck; if it is set too high it will price low-skilled workers out of the job market.

The Low Pay Commission is tasked with making recommendations on the minimum wage. The Commission examines issues such as: the changes in earnings since the minimum wage was last increased in 2011; unemployment and employment rates generally; the expected impact of a change to the minimum wage on employment, the cost of living and national competitiveness; and. changes in income distribution. It may also consider risks of a low-income trap, which would occur without coordination with other 
policies: high marginal effective tax rates at and just above the minimum wage level would restrain earnings prospects. (OECD, 2015a).

Given the change in the bargaining regime to firm level, the business sector has a stronger role in delivering a high quality working environment and jobs. The broad parameters of how the business sector runs are determined by foundation governance arrangements. Such arrangements should create a business environment that encourages a more medium-term focus for business such as providing training and education relevant to the labour market and generating high quality jobs.

The OECD Principles of Corporate Governance (OECD, 2015b) help policymakers evaluate and improve the legal, regulatory, and institutional framework for corporate governance. Implementation of the Principles supports economic efficiency, sustainable growth and financial stability, helping to ensure the flow of external capital to companies both in the form of equity and credit. In Ireland, corporate governance standards are largely self-regulated and similar to those in the UK due to the similarities in accounting and legal systems. In addition, a body of Company Law regulates how companies should be structured, governed and managed (IBEC, 2010). Companies listed on the stock exchange either have to comply with its corporate governance requirements in the Stock Exchange (which include the provisions of the UK Combined Code) or have to explain the reason for non-compliance. Overall, the Irish corporate governance framework adheres to most of the OECD Principles and is considered to be well-performing, especially in terms of protection of investors, transparency of transactions and redress for violation of shareholders' rights.

As in other OECD countries, Ireland also faces a new challenge with the increasing influence of institutional investors, which the revised OECD Principles particularly deal with (OECD, 2015b). The share of equity investment held by institutional investors such as hedge funds and high frequency traders has increased significantly, with the direct relationship between the long-term performance of the company and the prosperity of the shareholder being broken (Isaksson and Celik, 2013). The growth of such intermediations has increased the potential for misaligned incentives and is likely to have encouraged economic short-termism (The Kay Review, 2012). Some countries have already introduced institutional investor codes to promote engagement in corporate governance and align institutional investors' interests with the ultimate beneficiaries (savers). The notable example of such codes is the UK Stewardship Code, which Ireland should consider following. The revised OECD Principles also recommend increasing disclosures for intermediaries, to ensure alignment of incentives and to take an active long-term interest in the companies.

Corporate governance is also concerned with finding ways to encourage the various stakeholders in the firm to undertake economically optimal levels of investment in firm-specific human and physical capital (OECD, 2015b). In Ireland, stakeholders' rights are laid down by case law: for instance, directors are required to have regard to the interest of the company's employees and members since the early 1990s (IBEC, 2010). However, it is not clear what the interest of the employees exactly means, for example, what it stands for in terms of investment in firm-specific human capital. Given the stronger role of firms in the bargaining process, the corporate governance framework should have a clear focus on encouraging investment in human capital. In turn, such arrangements would require that the corporate governance framework itself should be built on the performance of the company from a long-term perspective.

Multi-national companies (MNCs) in Ireland place much value on human capital. Their business model differs, but they commonly hire talented people and provide considerable amount of firm-specific training. Such training programmes are not necessarily limited to entry levels but generally provided over the course of career. Their emphasis on human capital is also reflected more broadly in terms of career development plans or job portfolio management. The enterprise value of MNCs in Ireland is generally very 
high, reflecting what they will be producing over the future, and high quality human capital seems to be an essential asset underpinning such valuations.

For smaller firms with fewer resources to invest, more collective approaches, including cooperating with large firms, would be appropriate. FIT, is a notable example of such an approach. FIT is an industryled initiative, involving leading high-tech companies such as IBM. It's partly financed by the government and aims to act as bridge between the ICT industry and colleges, is a notable example of such approaches. FIT works also in close collaboration with government departments and national education and training agencies (including SOLAS and Education and Training Boards), local development organisations and a host of community based organisations. FIT identifies skill needs (according to which, there are more vacancies for people with skills at Level 5/6 on the National Framework of Qualifications than at the higher levels) and promotes technology-based programmes (apprenticeships) combining classroom training with workplace experience. The programmes develop not only ICT skills but also communication skills, project management, marketing and business acumen.

\section{Box 1. Corporate Investment in Human Capital}

There is an opportunity to create a business environment that encourages a more medium-term focus for business and greater corporate sector involvement in broader societal challenges, such as providing training and education relevant to the labour market and generating high quality jobs. For individual firms, such involvement could be beneficial on its own, enabling them to enjoy better public relations and reputation among stakeholders, and ultimately benefiting the economy as a whole in which they operate.

\section{Outreaching potential talents: Google's sponsorship in education programmes}

Google sponsors a postgraduate certificate course in $21^{\text {st }}$ Century Teaching and Learning launched at Trinity College Dublin. This programme aims to affect a significant long-term change in STEM education through a range of innovative interventions focused on the second level system. Google has provided funding of $€ 1.5$ million to the College to support the programme. In this programme, 400 teachers are expected to take this certificate over the next three years. A further 600 teachers will have the option to take individual workshops or complete three course modules to earn a certificate of participation. Teachers participating in the programme will learn best practice in the use of technology in the classroom and consider related issues in respect of leadership and change management, inclusive education and school/classroom based research.

Google has also supported other programmes in the College, such as the Trinity Access Programmes (TAP) encouraging those who come from socio-economic groups under-represented in higher education; and Bridge 21 offering a new model of learning - team-based, technology mediated, project based and cross-curricular - which can be adapted for use in Irish secondary school. 
ECO/WKP(2016)17

\section{Recommendations for increasing the inclusiveness of growth}

\section{Boost labour market participation and employment}

- Continue to improve the evaluation of training and activation programmes. Scale-up those that are effective in helping people to return to the open labour market. Shut-down the ones that are not.

- Upskill long-term unemployed by improving both the quantity and the quality of training via public employment services or via private funders,

- Ensure that students receive information on educational options after schooling, notably vocational and technical options. Make available and publicise widely information on graduates labour market status and wages by degree and institutions, both for university graduates and for those that followed vocational and technical paths.

\section{Improving mutual obligations}

- Evaluate the effects of tightened conditionality in place since 2012 on the recipient's commitments to active job search and re-employment prospects.

- $\quad$ Fully enforce e the obligations of the unemployed and improve the enforcement framework by defining more objectively the suitable offer which the benefit recipient has to accept in terms of wages and contract types.

\section{Improving the incentives to work by reducing welfare and income traps}

- To reduce welfare traps, more gradually reduce housing assistance payments and family income supplement as income increases.

- To increase the incentive to work for the low-paid, smooth the increase in marginal effective tax rates by introducing a third income tax bracket and more gradually increasing universal social charge and payrelated social insurance rates.

- To increase the incentive to work for families, reduce more gradually the family income supplement as income increases.

\section{Ensuring fiscal revenue and spending is more efficient and equitable}

- $\quad$ Consider further reducing tax allowances for capital income from lump sum pension payments.

- Increase the local property tax rate and simultaneously introduce a low-income waiver to protect poorer households.

- $\quad$ Eliminate reduced VAT rates for restaurant meals and accommodation.

\section{Wage setting}

- Monitor regularly the effects of the minimum wage on employment patterns and adjust where necessary to ensure the low-skilled are not priced out of the labour market.

- Take into account the risk of a low-income trap when setting the minimum wage. Coordinate with other 
ECO/WKP(2016)17

policies to avoid high marginal effective tax rates at and just above the minimum wage level.

\section{Corporate governance}

- Adopt institutional investor's codes to ensure alignment of incentives and to take an active long-term interest in the company.

- Together with social partners foster a strong business sector focus on building human capital through job training and career management. 


\section{BIBLIOGRAPHY}

AGTSW (Advisory Group on Tax and Social Welfare) (2012), "First Report: Child and Family Income Support”. 27 March 2012.

Attanasio, O., J. Banks and M. Wakefield (2004), "Effectiveness of Tax Incentives to Boost (Retirement) Saving: Theoretical Motivation and Empirical Evidence", IFS Working Papers, W04/33, Institute for Fiscal Studies, http://dx.medra.org/10.1920/wp.ifs.2004.0433.

Auten, G., and G. Gee (2009) "Income Mobility in the United States: New Evidence from Income Tax Data", National Tax Journal, vol.62, no.2.

Autor, D., F. Levy, and R. Murnane (2003), "The Skill-Content of Recent Technological Change: An Empirical Exploration”, Quarterly Journal of Economics, Vol.118, 1279-1333.

Bassanini, A. and T. Manfredi (2012), "Capital's Grabbing Hand? A Cross-country/Cross-industry Analysis of the Decline of the Labour Share", OECD Social, Employment and Migration Working Paper, No. 133, OECD Publishing, http://dx.doi.org/10.1787/5k95zqsf4bxt-en.

Bentolila, S. and G. Saint-Paul (2003), "Explaining Movements in the Labor Share", Contributions to Macroeconomics, Vol. 3, No. 1.

Bloom, N., M. Draca and J. van Reenen (2011), "Trade Induced Technical Change? The Impact of Chinese Imports on Innovation and Information Technology", CEP Discussion Paper, No. 1000.

Callan, T., N. Crilly, C. Keane, J.R. Walsh and Á. Ní Shúilleabháin (2011), "Tax, Welfare and Work Incentives" in Budget Perspectives 2012, Economic and Social Research Institute Ireland.

Central Statistics Office (2015), Household Finance and Consumption Survey 2013.

Chetty, R., J.N. Friedman, S. Leth-Petersen, T. Nielsen and T. Olsen (2012), “Active vs. Passive Decisions and Crowd out in Retirement Savings Accounts: Evidence from Denmark" , NBER Working Papers, No. 18565, National Bureau of Economic Research, www.nber.org/papers/w18565.pdf.

Dahl, C.M., D. le Maire and J.R. Munch (2011), "Wage Dispersion and Decentralization of Wage Bargaining”, IZA Discussion Paper No. 6176, Bonn, November.

Denk, O. (2012), "Tax Reform in Norway: A Focus on Capital Taxation", OECD Economics Department Working Papers, No. 950, OECD Publishing, http://dx.doi.org/10.1787/5k9bls0vpd5d-en.

Denny, K. (2015), "The evaluation of the School Support Program under DEIS": An assessment". UCD Geary Institute for Public Policy. Policy Peer Reviews series. Geary PPR2015.02.

Department of Social Protection, National Action Plan for Social Inclusion 2007-2016, Dublin.

Engen, E.M., W.G. Gale and J.K. Scholz (1996), "The Illusory Effects of Saving Incentives on Saving", Journal of Economic Perspectives, Vol. 10, No. 4, American Economic Association.

Eurostat (2014), Survey on ICT Usage and Ecommerce. 
González Pandiella, A. (2013), "Getting Irish Youth on the Job Track", OECD Economics Department Working Papers, No. 1101, OECD Publishing, http://dx.doi.org/10.1787/5k3twr9k6s7h-en.

Hijzen, A. and P. Swaim (2010), "Offshoring, Labour Market Institutions and the Elasticity of Labour Demand”, European Economic Review, Vol. 54, No. 8, pp. 1016-1034.

IBEC (2010), Corporate restructuring guidelines: Corporate governance, Irish Business and Employers Confederation.

Isaksson, M. and S. Çelik (2013), "Who Cares? Corporate Governance in Today's Equity Markets", OECD Corporate Governance Working Papers, No. 8, OECD Publishing, http://dx.doi.org/10.1787/5k47zw5kdnmp-en.

Johansson, A. et al. (2008), "Taxation and Economic Growth", OECD Economics Department Working Papers, No. 620, OECD Publishing, http://dx.doi.org/10.1787/241216205486.

Kay Review (2012), The Kay Review of UK Equity Markets and Long-term Decision Making, Department for Business, Innovation \& Skills, London, www.bis.gov.uk/assets/biscore/business-law/docs/k/12917-kay-review-of-equity-markets-finalreport.pdf.

Keane, C. (2012). To Study or to Work? The Impact of a Construction Boom on Male Educational Attainment”. Ph.D. Thesis Chapter. University College Dublin: Ireland.

Keane, C. (2014), Gender Impact of Tax and Benefit Changes: A Microsimulation Approach, ESRI Working Paper, Economic and Social Research Institute, Ireland.

Keane, C., J.R. Walsh, T. Callan, M. Savage (2012), "Property Taxes in Ireland: Key Choices", ESRI Renewal Series, Paper 11, Economic and Social Research Institute, Ireland.

Kelly, E., E., S. McGuinness, P. O'Connell, A. González Pandiella, and D. Haugh (2015), "How Well Does Ireland Integrate Migrants into its Labour Market?", OECD Economics Department Working Papers, forthcoming.

Kennedy, S., Y. Jin, and D. Haugh (2015), "Taxes, Income and Economic Mobility in Ireland: New Evidence from Tax Records Data", OECD Economics Department Working Papers, forthcoming.

Lamare, J.R., P. Gunnigle, P. Marginson and G. Murray (2009), "Multinationals' Union Avoidance Practices at New Sites: Transatlantic Variations", Paper for MNCs Symposium, IIRA World Congress, Sydney, August.

McGuinness, S., E. Kelly, and P. O’Connell (2008), “The Impact of Wage Bargaining Regime on FirmLevel Competitiveness and Wage Inequality: The Case of Ireland", ESRI Working Paper, No. 266, Economic and Social Research Institute, Ireland.

McGuinness, S., O’Connell, P., and Kelly, E., (2014), "The Impact of Training Programme Type and Duration on the Employment Chances of the Unemployed in Ireland", The Economic and Social Review, 45, Autumn 2014, 425-450.

Maître, B., H. Russell and C.T. Whelan (2014), "Trends in Economic Stress and the Great Recession in Ireland", Department of Social Protection Social Inclusion Technical Paper, No. 5. 
Nolan, B., B. Maître, S. Voitchovsky and C.T. Whelan (2012), "Inequality and Poverty in Boom and Bust: Ireland as a Case Study", AIAS Gini Discussion Paper.

O’Connell, P. (2015), ““'The 2013 Follow-Up Survey of Former FÁS Trainees”: An Assessment”. UCD Geary Institute for Public Policy. Policy Peer Reviews series. Geary PPR2015.02.

O'Connor, B. T. Hynes, and D. Haugh (2015), “The Distributional Consequences of Growth and Employment Enhancing Tax and Welfare Changes in Ireland", OECD Economics Department Working Papers, forthcoming.

OECD (2007), OECD Employment Outlook 2007, OECD Publishing, Paris, http://dx.doi.org/10.1787/empl_outlook-2007-en.

OECD (2011) OECD Economic Survey of Ireland, OECD Publishing, Paris, http://dx.doi.org/10.1787/eco_surveys-irl-2011-en.

OECD (2012), OECD Employment Outlook 2012, OECD Publishing, Paris, DOI: http://dx.doi.org/10.1787/empl_outlook-2012-en.

OECD (2013a), OECD Employment Outlook 2013, OECD Publishing, Paris, http://dx.doi.org/10.1787/empl_outlook-2013-en.

OECD (2013b) OECD Economic Survey of Ireland, OECD Publishing, Paris, http://dx.doi.org/10.1787/eco_surveys-irl-2013-en.

OECD (2014), OECD Science, Technology and Industry Outlook 2014, OECD Publishing, Paris, http://dx.doi.org/10.1787/sti_outlook-2014-en.

OECD (2015a), OECD Employment Outlook 2015, OECD Publishing, Paris, http://dx.doi.org/10.1787/empl_outlook-2015-en.

OECD (2015b), OECD Principles of Corporate Governance, OECD Publishing, Paris.

O'Connor, B., (2013), "Measuring the Impact of the Jobs Initiative: Was the VAT reduction passed on and were jobs created?", Administration, 60, pp 161-179,

O'Connor, B., Heynes, T., and D. Haugh (2015), "The Distributional Consequences of Growth and Employment Enhancing Tax and Welfare Changes in Ireland", OECD Economics Department Working Papers, forthcoming.

Public Policy (2013), Budget 2014: The Reduced Rate of VAT available at: http://www.publicpolicy.ie/budget-2014-9-rate-vat/

Savage, M., Callan, T., C. Keane, E, Kelly and J.R. Walsh (2014), "Welfare Targeting and Work Incentives", Budget Perspectives 2015 Paper 3, Economic and Social Research Institute Ireland.

Savage, M., Colgan, B., Callan, T., and J.R.Walsh (2015), "Making Work Pay More: Recent Initiatives", Budget Perspectives 2016 Paper 2, Economic Social Research Institute Ireland.

Thomas, A. (2015), OECD Consumption Tax Micro-Simulation Model Results, Centre for Tax Policy, OECD, Paris. 
ECO/WKP(2016)17

Voitchovsky, S. B. Maître and B. Nolan "Wage Inequality in Ireland's Celtic Tiger Boom", Economic and Social Review, Vol. 43., No. 1 Spring 2012 pp 99-133. 